\title{
فاعلية برنامج مقترح قائم على المدخل التواصلي في تنمية مهارات الحوار لدى طلاب المرحلة التتوسطة فئل
}

\section{أحمد عجي الهيلي}

هدفت الدراسة الكشف على فاعلية برنامج مقترح قائم على المدخل التواصلي في تنمية مهارات

الحور لدى طلاب المرحلة المتوسطة.واستخدم الباحث المنهج التجريبي في تصديمه شبه التجريبي.

وتكونت عينة الدراسة من ( Tr ) طالبًا تم اختبارهم بطريقة عشوائية من إحدى المدارس التابعة لإدارة

التعليم بالمخواة وتم تقسيههم إلى مجدوعتبن متكافئتين إحداهما ضابطة و الأخرى تجريبية، حبث درست

المجدوعة التجربيية وفقاً للبرنامج القائم على المدخل التواصلي بينما درست المجدوعة الضابطة المنهج

بالطريقة المعتادة، وبعد الانتهاء من التدربي تم تطبيق أدوات الدراسة والمتمثلة في (مقياس الاتجاه نحو

مهار ات الحوار ـ بطاقة ملاحظة مهارات الحوار ) على مجموعتي الدراسة وذلك للكثف عن فاعلية

البرنامج القائم على المدخل التواصلي في تتمية مهارات الحوار للى طلاب المرحلة المتوسطة. وقد

توصلت الدراسة إلى عدة نتائج أهدها: فاعلية البرنامج القائم على المدخل التواصلي في تتمبية مهارات

الحوار لدى طلاب المتوسطة حبث تبين وجود فروق ذات دلالة احصائية عند دستوى ( 0,05 ) بين

متوسطات درجات طلاب المجموعة التجريبية ودرجات طلاب المجموعة الضابطة في مقياس الاتجاه نحو

مهار ات الحوار لصالح طلاب المجموعة التجربيية .وكذلك وجود فروق ذات دلالة احصائية عند مستوى

(0,05) بين متوسطات درجات طلاب المجدوعة التجربيية ودرجات المجدوعة الضابطة في بطاقة

ملاحظة مهارات الحوار لصالح طلاب المجدوعة التجريبية .

\section{Abstract}

Study title: the effectivenss of a program that bassed on communication portal to improve dialogue skills among studnts in the intermediate stag.

the goal of study to know how this program affects this skill in the intermediate stage.- study Approach: this study was followed design based on dividing into two egual groups. The first one is officer and the other is empiricict .The experimental groups were studied a cording to the program that based on the communication fortal while the officer groups studied the usual convenentional approach.After we have finished from teaching we application to both groups to know the affects. The study population: All students in the second grade are average in general education in the public schools in Al-makhwah governorate amd are between (12-13)Study sample : the study sample consisted of ( 36) randomly selected students from the princ sultan school of education department in Almakhwah. They were divided into two experimental groups, ( 18 ) students and the 
other ( 18 ) students.Study tools: 1- dialogue skills scale. 2- notn card dialogue :Results: The results of the present study resulted in ascertaining the effectiveness of the proposed program based on the communicative approach in developing dialogue skills among middle school students, as follows:- There were statistically significant differences at ( 0.05$)$ between the average scores of the experimental group and the students of the control group in the dialogue skills scale for the students of the experimental group.- The existence of statistical differences at the level of $(0,05)$ between the average scores of the students of the experimental group and the control group scores in the note card dialogue skills for the students of the experimental group.

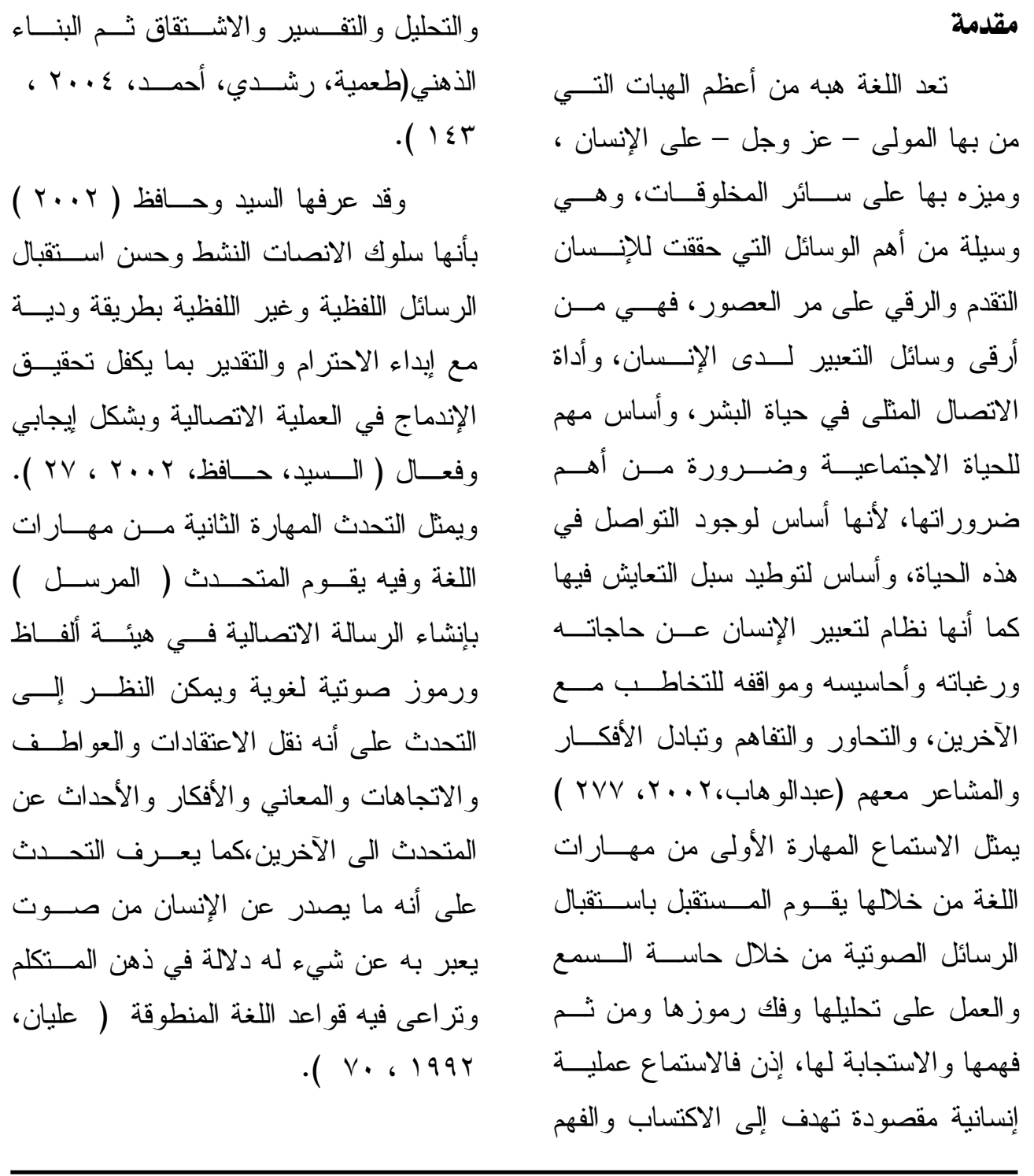


مع زملائه ومـع المعلم للوصول إلى أفــضل فئل

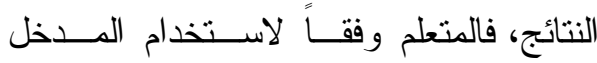

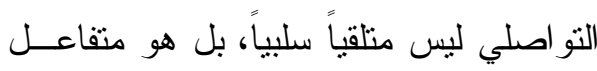

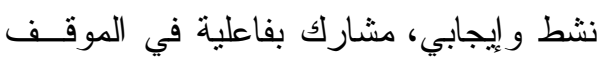
التعليمي إرسالاً واستقبالاً ولقد أكدت العديد

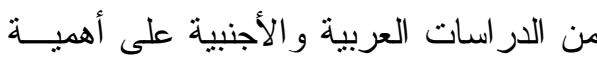

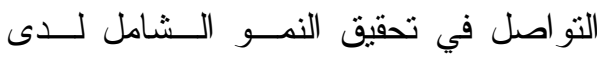
الطلاب لغوياً ونفسياً وسلوكياً و ونها در اســـة

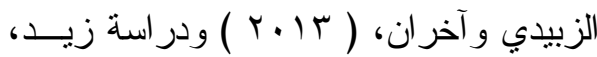

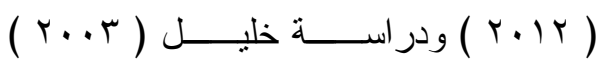
ودراسة ( numan, david,1996) و لأهمية التو اصل فقد ظهر الاهتمــام

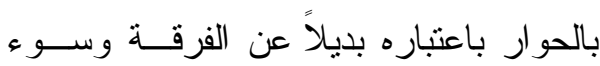

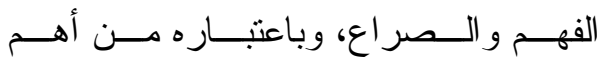
ضرور ات العصر لحاجة الناس إلى التفاعـل فـل

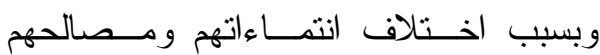

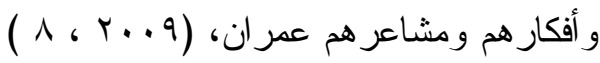
و الحوار وسيلة للإفهام ومتتفساً ينيح للمـتنعلم التعبير عما تجيش به نفسه، كما أن الحــوار

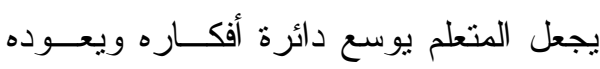
التفكير المنطقي ويقوده نحو ارتجال المواقف دُقات الحياتية المختلفة معتمداً على فصاحة لسانه، ولا يخفى دور الحوار في وضعه حداً فاصلاً

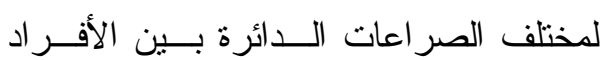

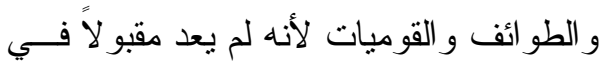
هذه الآونة الأخيرة النطرف في الفكر و العمل

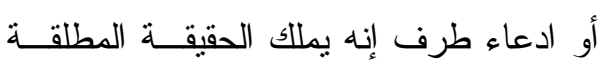

كما ظهر تبعاً لذلك المدخل التواصلي الأي يعد من أهم مداخل تدريس اللغة العربية نظر أ لقدرته على تـــوفير الأسـس المهـــــة المساعدة على تعليم اللغة بصورتها الطبيعية

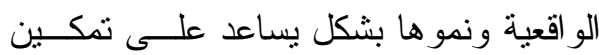
الطلاب من إتقان المهار ات اللغوية واستخدام قو اعد اللغة لأداء وظائف اتصالية في مو اقف

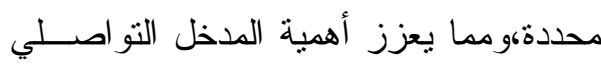
أنه يؤكد على ضرورة تحقيق التكامل بــين المهار ات الأساسية الاستماع و الكلام و القر اءة

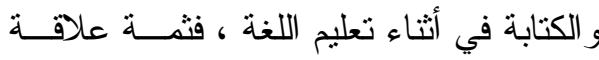

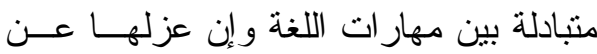
بعضها البعض في تعليم اللغة يفقد المهــارة

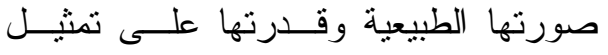

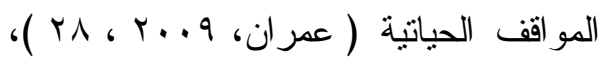
فأهمية المدخل التواصلي تكمن ، في كونــهـ يضع المتعلم في مو اقف طبيعية تعكس البيئة

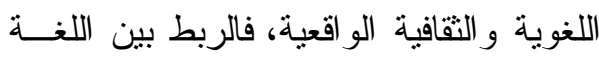
وبيئتها وو اقعها في كل ما يتم تقديمسـه مــن

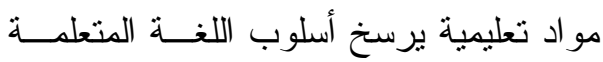

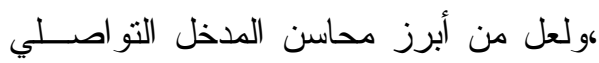

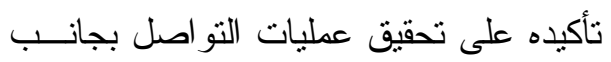
إتقان الصيخ اللغوية، وهذا يؤدي إلــى أدوار

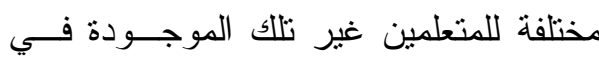
المداخل التقليدية، حيث يتسم دور المتعلم في المدخل التو اصــلي بالإيجابيــة و المــشاركة الفاعلة فهو يشارك بإبداء رأيه ويتعاون دائما 
مشكلة الدراسة

تتمنل مشكلة الدراســـة فـي وجــود

قصور و اضح لاى الطلاب فــي مهــار ات

الحوار ذلك على الرغم من أهمية مهــار ات

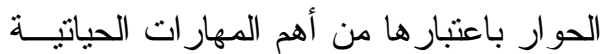
و التواصلية التي يجب التركيز عليها وتتميتها

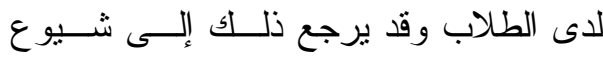
الطرق الثقليدية في تدريس اللغـــة العربيــة، وعــدم الاهتمــام الكـــافي باســـنر اتيجيات التدريس الحديثة التي تعهـلـل عـــى إتقـــان المهار ات اللغوية وتكاملها، وبالرجوع إلــى لتعلى

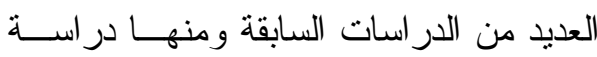

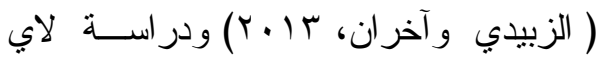

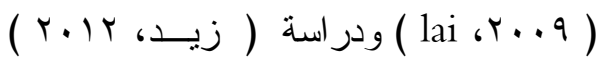

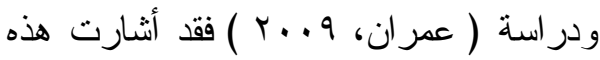
الدر اسات إلى وجود قصور لاى الطلاب في التمكن من مهار ات اللغة العربية على نحسـو

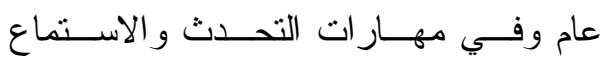
و استتخدام اللغة العربية استخداماً سليماً فـي والي مو اقف طبيعية وقد أرجعت هذه الدراســات

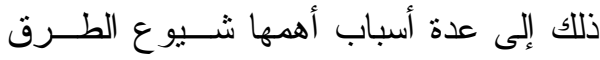

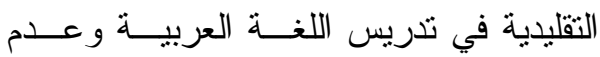

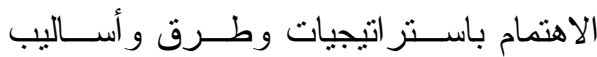

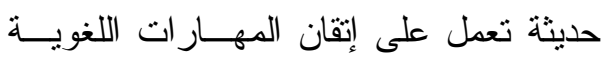
وتكاملها.

وقد قام الباحث بدر اسة اســنطلاعية لمجموعة من طلاب المرحلة المتوسطة بلغ لباحن

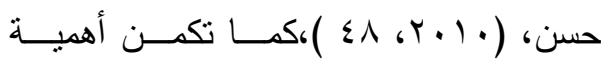

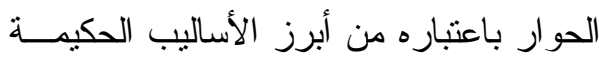

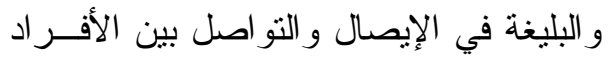

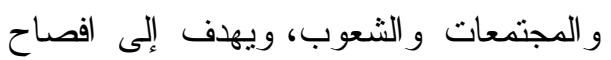
كل طرف عما لديه من أفكــار و آراء ليــتم

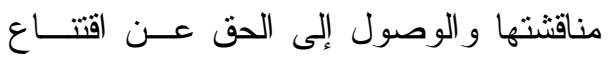
عقلي وارنياح نفسي، و اطمئنان وجداني، كما

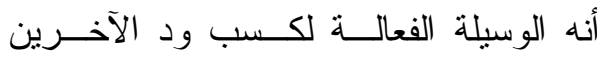

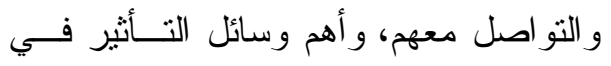
الآخرين وتغيير الميول و الاتجاهـات مــن

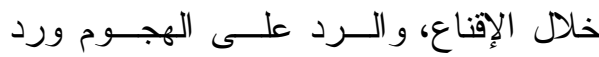

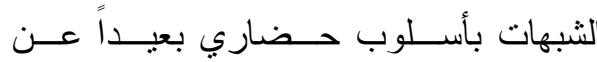
التعصب و الإصر ار و العناد الذي يؤدي إلــى بـى

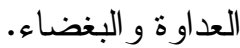
ولبناء مهار ات الحوار لدى الطـــلاب عني الباحثون بتوظيف طر ائق تدريس حديثه ترتكز على محورية الطالـــب فـــي العمليــة التعليمية ، فقد تحول تدريس اللغة العربيــة من الطر ائق التقليدية إلى الطر ائق التواصلية،

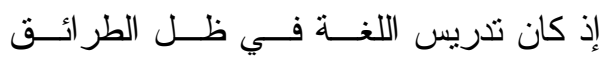

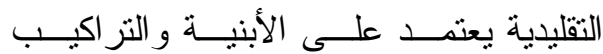
و التكـــر ار الآلــي، ومـــع منحـــى المــدخل

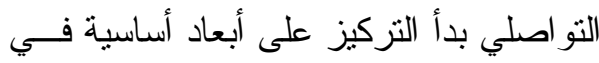

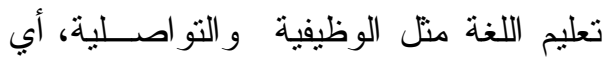

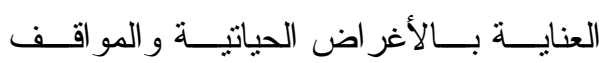

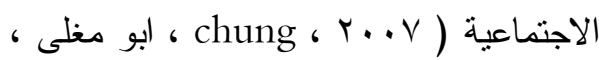
$(r . .0$ 
r- الكثف عن فاعلية البرنامج المقتـرح

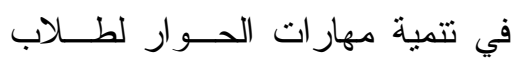

$$
\text { الصف الثاني المتوسط. }
$$

- الدراسات السابقة

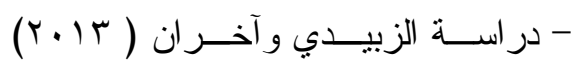

هدفت الدراسة الكثف عن أثر برنــامج

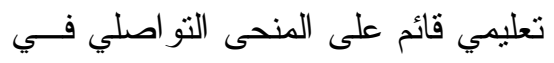

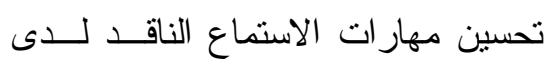
طلبة الصف التاسع الأساسي.

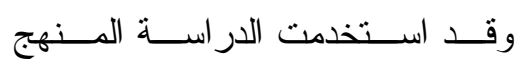

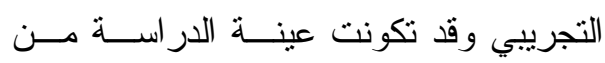

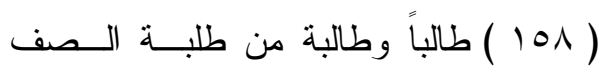

التاسع الأساسي في مدرستين حكوميتتين هما

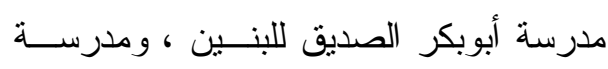

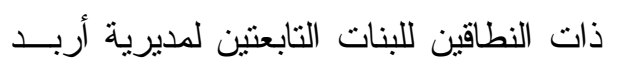

$$
\text { الأولى. }
$$

- وقد اختيرت شعب أفراد الدراسة مــن

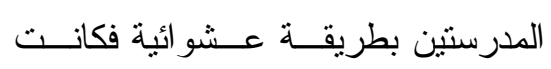

الثعبتان ( أ ، ب ) في مدرسة أبــوبكر

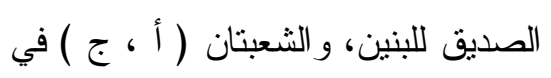

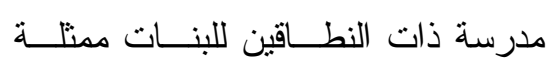

لأفر اد هذه الدر اسة حيث منلت الشعبتان

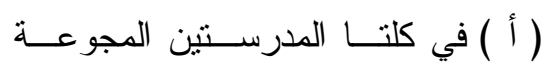

الضـابطة.

وقد أظهرت النتائج وجود فروق ذات

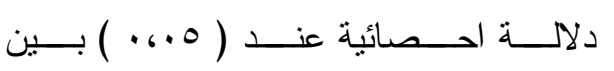

عددهم نحو ( ب م ) طالباً من طلاب الصف الثاني المتوسط، وذلك لملاحظة مدى تمكنهم

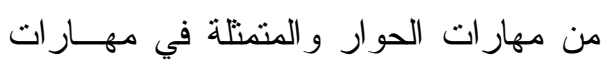

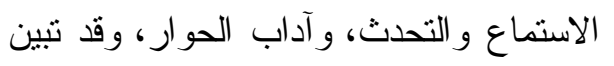

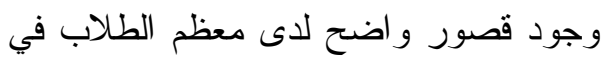

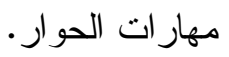
ومن خلال خبرة الباحث في العهـلـل

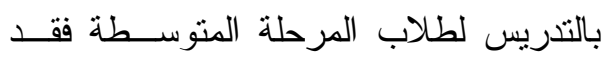

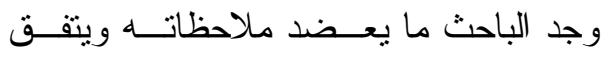
مع ما أكدته العديد من الدراســات الــسابقة حيث تبين وجود قصور لدى معظم الطلاب

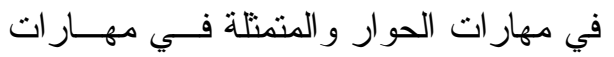

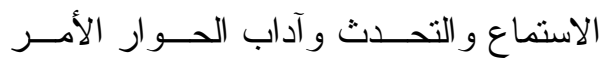

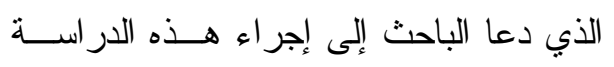

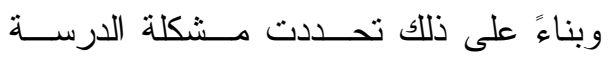
الحالية في الكثف عن فعالية برنامج مقترح

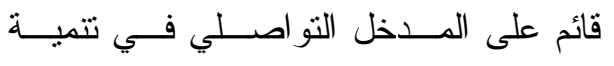

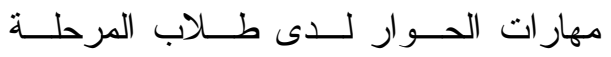
المتوسطة. أهداف الدراسة تتمنل أهداف الدر اسة الحالية فيما يلي 1- تحديد مهار ات الحوار اللازمة لطلاب الصف الثاني المتوسط. r - بناء برنامج مقتر ح قائم على المــدخل

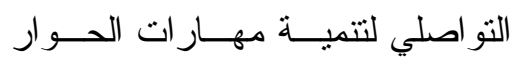
لطلاب الصف المتوسط. 
ضبط الأداء القبلي لصـالح طــلاب المجموعة التجريبية.

r- وجود فروق ذات دلالة احـصائية

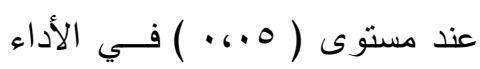

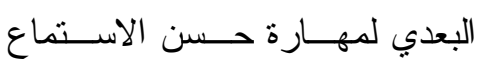

والانصات بعد ضبط الأداء القبلــي البـي

لصالح المجموعة التجريبية.

צ- دراسة زيد (r r r r )

هدفت الدراسة التعرف على فاعليــة

برنامج قائم على المواقف الحوارية لتتميـــة

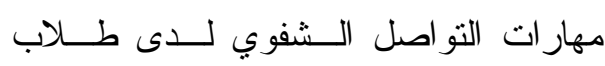
المرحلة الثانوية العامــة فـي مــادة اللغـــة العربية، وقد اســتخدمت الدراســـة المــنهج

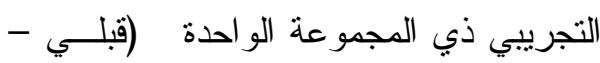

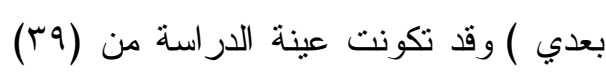

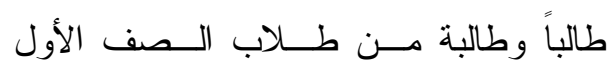

الثانوي بمدرسة ناصر الثانوية المشتركة.

وقد تمثلت أدوات الدراسة فيما يلي :

أ- قائمة مهار ات النو اصل اللغوي اللازمة

$$
\text { لطلاب الصف الأول الثانوي. }
$$

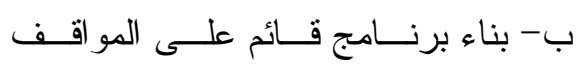

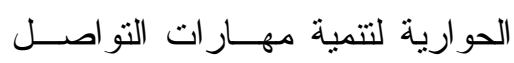

$$
\text { الثفوي. }
$$

ج- إعداد اختبار مو اقف لقياس مهــار ات

$$
\text { النو اصل اللغوي الثفوي. }
$$

المجمو عتنن التجريبية و الضابطة تعزى إلى

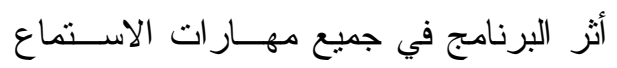
ولصالح المجموعة التجريبية. كما لم تظهر النتائج فروقاً ذات دلالة

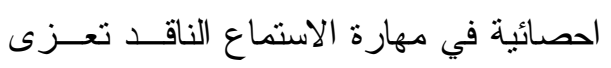
للجنس أو التفاعل بين الطريقة و الجنس.

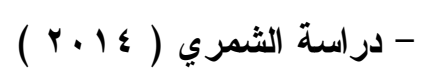
هدفت الدراسة التعرف على فاعليــة التدريس باستر اتيجية لعب الأدوار في تتميـــة

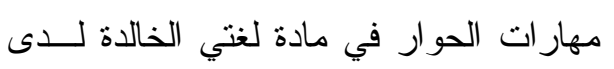
طلاب الصف الثالث المتوسط وتحقيقاً لهـــا

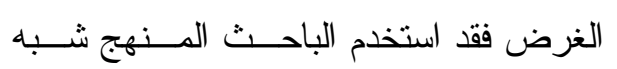
التجريبي وتكونت عينة الدراسة من ( 101 ) طالب تم تقسيمهم إلى مجمــو عتين إحـــــاها

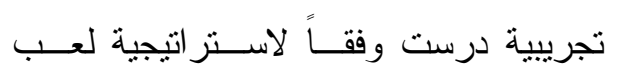
الأدو ار وتكونت من ( ro ) طالب و الأخرى

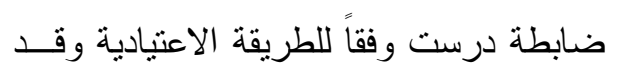
تكونت من ( Tr ) طالب - وتمنلت أداة الدر اسة من مقياس للحوار قام

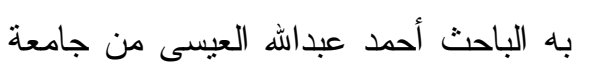

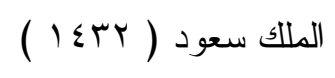

وقد توصلت الدراسة إلى عدة نتائج أهمها :

1- وجود فروق ذات دلالة احـصائية

عند مستوى ( 0.، . ) فــي الأداء

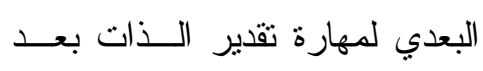


وتم استخدام اختبار آخر تضمن ســلم

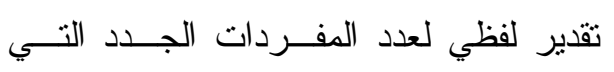

استخدمها الطالب أثناء التحدث.

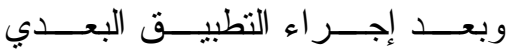

للاختبار ات نتين أن نسبة المفردات الجديــدة

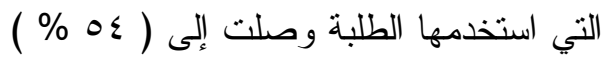

من المجموع العام للتحدث، وتمكن الطلبـــة

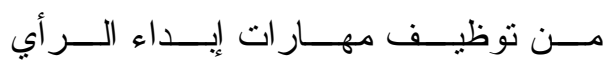
وتمثيل المواقف بالأدلة أثثاء الحــديث، وأن

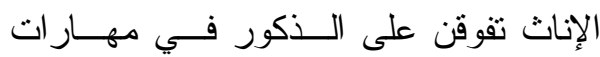
العرض والقــدرة علــى تتـسيق الأفكـار

وتز ابطها.

منهج وإجراءات الدراسة

منهج الار استة:

استخدم الباحــث المـــــــ التجريبــي

لمناسبته لطبيعة البحث

مجتمع الدراسة:

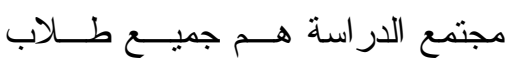

الصف الثاني المتوسط في التعليم العام فـي هي

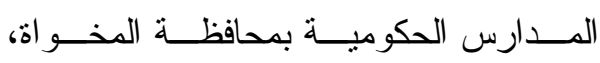

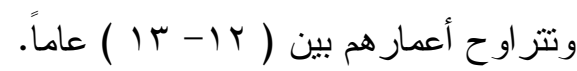

$$
\text { عينة الدر اسة: }
$$

وتم اختيار عينة الدراسة من مدرســة

الأمير سلطان التابعة لإدارة تعليم المخواة

تم اختيار أحد الفصول عشوائًا عـن

طريق القرعة ليمثل المجموعـــة الــضابطة
- وقد توصلت الدراسة إلى عـدة نتــائج

أهمها:

وجود فروق دالة احصائياً بين متوسط

درجات الطلاب عينة الدراسة على اختبـار

مهار ات التواصل الثفوي في النطبيق القبلي

و البعدي ولصالح النطبيق البعدي الأمر الذي في لني

يدل على فاعلية البرنامج المقترح القائم على لئى لئحي

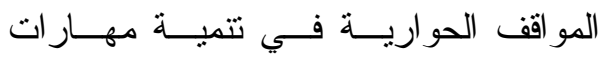

التواصل الثفوي لاى طلاب الــصف الأول

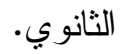

( opel , 2008 ) دراسة أوبل )

هدفت الدراسة إلى الكثف عن أثــر

الطريقة الحواريــة فــي اكتــساب أطفــال

المرحلة الأساسية في بــنجلاديش لمهــار ات

التحــدث ، و المفــردات فــي مـــادة اللغـــة

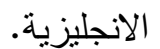

- وتحقيقاً لأهداف الدر اسة استخدم الباحث

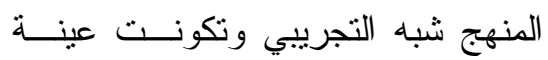

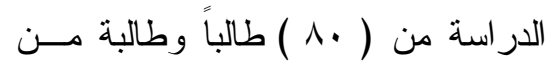

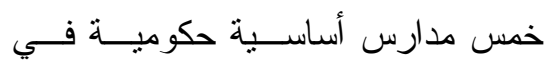

بنجلاديش، شاركو ا في برنامج در اســي

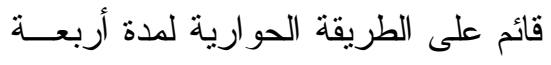

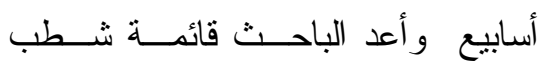

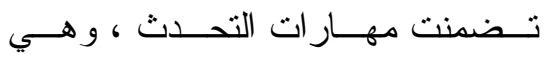

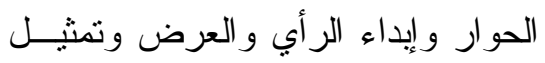

المو اقف. 
๑. تحديد أوجه النشاط التي يمكن القيــام بها في البرنامج. T. تحديد التقويم في البرنامج.

أهداف البرنامج:

من المتوقع بعد الانتهاء من دراســة

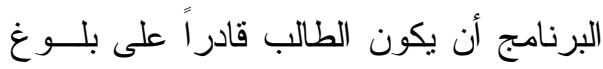

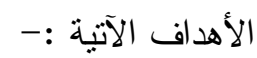
ا ـ تتمية الوعي بقضايا الثباب. r. اكتساب رصيد معرفي يساعد علـى بـى التو اصل حول قضايا الثباب. r. فهم نصوص الوحدة وتحليلها ونقدها.

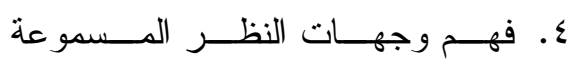
وتحليلها. 0. إعادة صياغة وجهة نظر مسموعة. T. تتمية الكفاءة التو اصلية لدى الطلاب. V. نتمية القدرة على التعبير عن الرأي. ( ) محتوى البرنامج: تم تحديد محتوى البرنامج في ضو ء :- الأهداف التعليمية للبرنامج. - قائمة مهار ات الحوار التي نم تحديدها. - طبيعة مقرر لغتــي الخالــــة بالــصف الثاني المتوسط.

$$
\begin{aligned}
& \text { - خـــــائص نمـــو طــلاب المرحلــــة } \\
& \text { المتوسطة. }
\end{aligned}
$$

و التي تضم (1/ ) طالباً، وفصل آخر بنفس

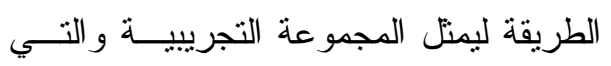
تضم ( 1) طالباً أدوات ومواد المعالجة التجريبية: تحددت أدوات الدر اسة الحالية في مجموعـــة من الأدوات البحثية، وهي: أ. قائمة مهار ات الحوار اللازمة لطلاب المرحلة المتوسطة. ب. مقياس الاتجاه نحو مهار ات الحوار. ج. بطاقة ملاحظة مهار ات الحوار.

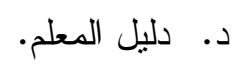
ه. كتيب أنشطة الطالب. ويمكن عرض بناء الأدو ات تفصيلاً على

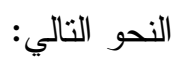

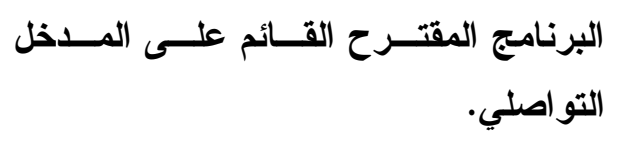
التو اصلي. قام الباحث بإعداد التصور المقتــرح للبرنامج القائم على المدخل التواصلي لتنمية

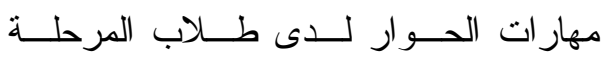
المتوسطة، منتعًا في ذلك الإجر اءات التالية : 1. تحديد الفلسفة العامــة أو المنطلقـات الفكرية للبرنامج. r. ت تحديد أهداف البرنامج. r. ت تحديد محتوي البرنامج. ع. تحديد طرق التدريس في البرنامج. 


$$
\begin{aligned}
& \text { r. مصادر إعداد المقياس. } \\
& \text { r. الصياغة الإجر ائية للمكونات. } \\
& \text { ء. التحقق من صدق المقياس. } \\
& \text { 0. التجربة الاستطلاعية للمقياس. } \\
& \text { 7. نظام التصحيح وتقدير الدرجات. } \\
& \text { V. الصورة النهائية للمقياس. } \\
& \text { وفيما يلي عرض لهذه الخطوات : } \\
& \text { ( ) تحديد الهرف من المقياس : }
\end{aligned}
$$

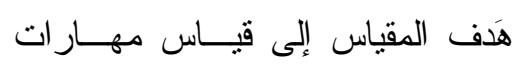

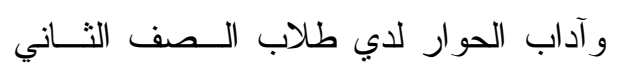

$$
\begin{aligned}
& \text { المتوسط. } \\
& \text { r ) مصادر إعداد المقياس: } \\
& \text { نم الرجوع إلى مصادر عدة في إعــداد }
\end{aligned}
$$

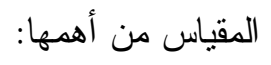

$$
\begin{aligned}
& \text { - } \\
& \text { المرحلة المتوسطة. }
\end{aligned}
$$

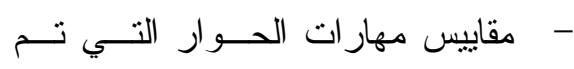

$$
\begin{aligned}
& \text { إعدادها في الدر اسات السابقة. } \\
& \text { - - الإطار النظري الذي تم إعــداده فــي } \\
& \text { الدر اسة الحالية. }
\end{aligned}
$$

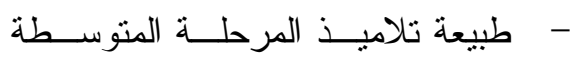

$$
\begin{aligned}
& \text { وخصائص نمو هم اللغوي. } \\
& \text { وقد راعى الباحث عنــــ تنظــيم المحتــوى } \\
& \text { الاعتبار ات الآتية : }
\end{aligned}
$$

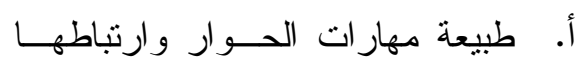

$$
\begin{aligned}
& \text { بالمحتوى الفعلي للمقرر الدر اسي. }
\end{aligned}
$$

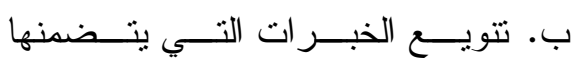

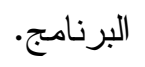

$$
\begin{aligned}
& \text { ج. مر اعاة التنظيم المنطقي و الــسيكلوجي } \\
& \text { أثثاء تتظيم المحتوى. }
\end{aligned}
$$

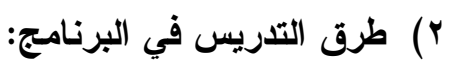

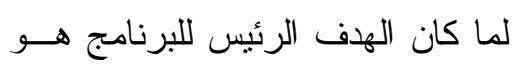

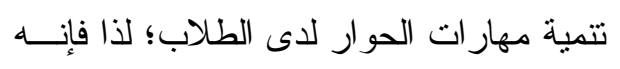

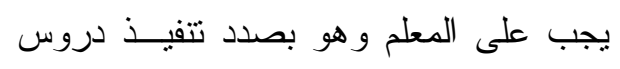

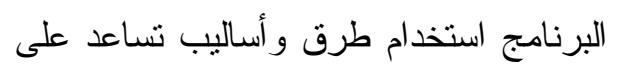

$$
\begin{aligned}
& \text { تحقيق أهداف البرنامج لا سيما و أنه برنامج }
\end{aligned}
$$

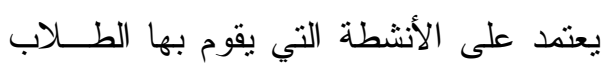

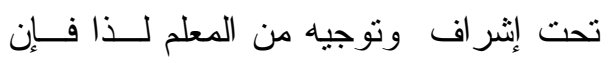

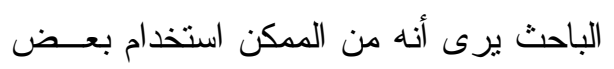

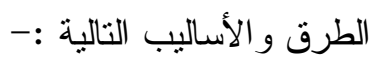

$$
\begin{aligned}
& \text { ا ا. ـ طريقة المناقشة. }
\end{aligned}
$$

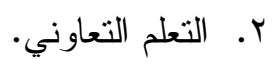

$$
\begin{aligned}
& \text { r. استر اتيجية النمذجة. } \\
& \text { ع. ـ استر اتيجية الحوار النشط. } \\
& \text { ه. استر اتيجية لعب الدور. } \\
& \text { أ. مقياس الاتجاه نحو مهارات الحوار. }
\end{aligned}
$$

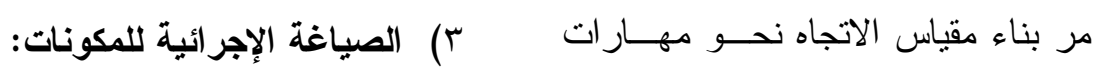

$$
\begin{aligned}
& \text { تكون المقياس في صورته الأولية من }
\end{aligned}
$$

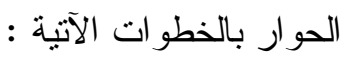

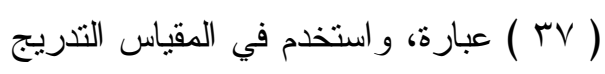

$$
\begin{aligned}
& \text { ا ـ إنحديد الهذف من المقياس. }
\end{aligned}
$$


الوضوح و الارتباط بالغرض الذي وضـــت

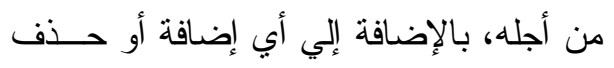

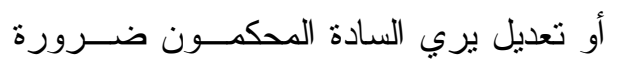
إضـافته إلي المقياس. وقد قام الباحث بـــإجر اء التتــديلات المطلوبة و التي اتفق عليها معظم المحكمـين وبذلك أصبح المقياس صالحا للتطبيــق فــي صورته النهائية. ملحق رقم ( ع ) 0) التجربة الاستطلاعية للمقياس: تــم تطبيــق المقبـــاس علــي عينــة استطلاعية مكونة من (19 ) طالب مـن خارج عينة الدر اسة الأساسية، وبعد إجــر اء التطبيق تم حساب ما يلي: أ.حساب معاملات السهولة لفقرات مقيــاس

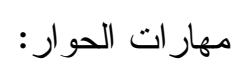

بعد تطبيق المقبــاس علــي العينــة الاستطلاعية وتصحيحها ثم حساب معاملات

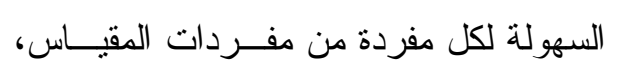
ويوضـح الجدول التالي نتائج حساب معامــلـ السهولة لمفردات المقياس.
الثثلاتي ( دائماً، أحياناً، نــادراً ) ). وكانـــ

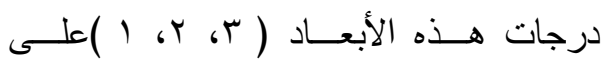
التزتيب، وبذلك تأخذ استجابة الطالب ســـو اء بالمو افقة أو المعارضة، فإذا كانت الدرجــة

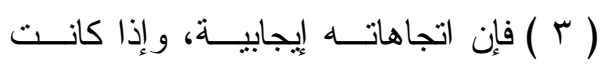

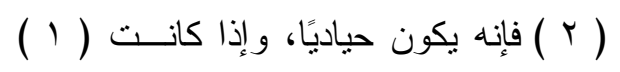
تكون اتجاهاته سلبية، وتــزداد الاتجاهـــات

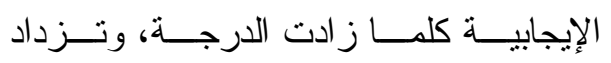
الاتجاهات الـسلبية كلهــا قلـــت الدرجـــة، و الدرجة القصوى للمقياس هي عبارة عـن عدد فقرات المقياس مضروبة في أعلى تقدير للاستجابة وهو ( ) أي Vr ×

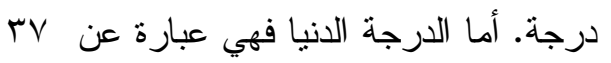

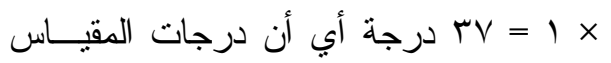
تتز اوح ما بين ( Vr إلى III ) درجة. ع) التحقق من صدق المقياس: للتحقق من صدق المقياس في صورته الأولية، تم عرض المقياس على مجموعــة من المحكمين ذوي الاختصاص وذلك للتحقق من مناسبة عبــار ات المقيــاس للمهــــار ات المنشودة، ومدى سلامة الــصياغة اللغويـــة و العلمية لعبار ات المقياس، ومــدي درجـــة 


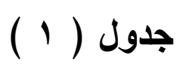

قيم معاملات السهولة لمفردات مقياس الاتجاه نحو مهارات الحوار

\begin{tabular}{|c|c|c|c|c|c|c|c|}
\hline السهولة & المفردة & السهولة & المفردة & السهولة معامل & المفردة & السهولة & المفردة \\
\hline •, Or & r & $\cdot, 01$ & r & $\cdot, 09$ & 11 & $\cdot, 09$ & 1 \\
\hline זT, • & rr & צ & rr & . & ir &., 00 & $r$ \\
\hline$\cdot, 7)$ & rr & $\cdot, \mathrm{r}$. & r & r & ir & $\cdot, 7)$ & $r$ \\
\hline., 01 & &., 01 & $r \varepsilon$ & r,or & $1 \leq$ & .,07 & $\varepsilon$ \\
\hline צ & r & . & ro & $\cdot, V^{\prime}$ & 10 & . & 0 \\
\hline .,$\leqslant 0$ & T & . & צ & זד, & 17 & זד, & 7 \\
\hline \multirow[t]{4}{*}{ •, 70} & $r v$ & $\cdot, 79$ & $r V$ & $\cdot, 7)$ & IV & $\cdot(7)$ & $v$ \\
\hline & & $\cdot, V_{1}$ & rA & $\cdot, \leqslant 1$ & 11 & $\cdot, V_{1}$ & $\wedge$ \\
\hline & & ., Or & rq & $\cdot, 01$ & 19 & •, or & 9 \\
\hline & &., 01 & $r$. &., 07 & $r$. &., 01 & 1. \\
\hline
\end{tabular}

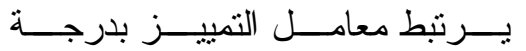

بظهر مــن الجـدول رقـم ( 1 ( ) أن

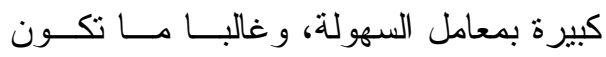

قيم معاملات السهولة قـــــتراوحسـت بــين

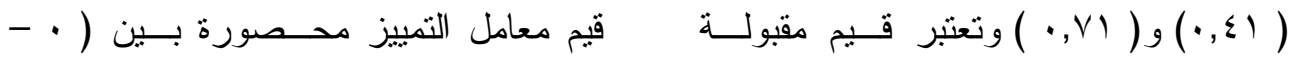

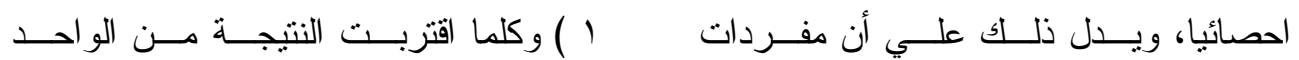

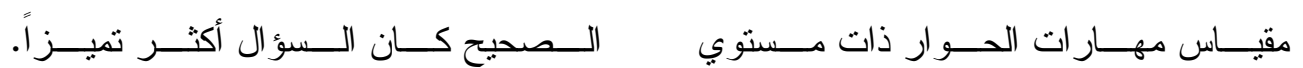

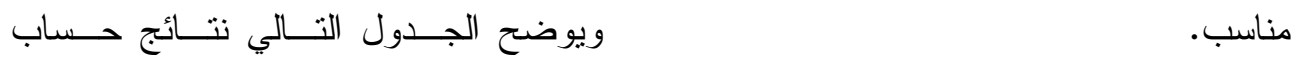

ب. حسـساب معساملات التمييـز لفقــرات معامل التمبيز .

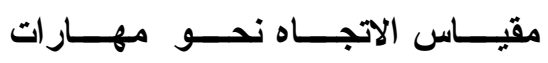

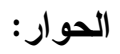




\section{جدول (r)}

قيم معاملات التمييز لمفردات مقياس الاتجاه نحو مهارات الحوار

\begin{tabular}{|c|c|c|c|c|c|c|c|}
\hline معامل & المفردة & التمييز & المفردة & التمييز & المفردة & معامل & المفردة \\
\hline$\cdot, 9 r$ & rI & $\cdot, 91$ & rI & $\cdot, \wedge 9$ & 11 & $\cdot, \wedge 9$ & 1 \\
\hline$\cdot, 9 r$ & rr & $\cdot, \wedge \leq$ & rr & $\cdot, \lambda 0$ & ir & $\cdot, 90$ & $r$ \\
\hline$\cdot, \wedge)$ & rr & $\cdot, 9$. & r & •, & 14 & $\cdot, 91$ & $r$ \\
\hline$\cdot, \lambda)$ & $r \varepsilon$ & $\cdot, \wedge \wedge$ & $r \leq$ & r, & $1 \varepsilon$ & $\cdot, 97$ & $\varepsilon$ \\
\hline$\cdot, \wedge \varepsilon$ & ro & $\cdot, 91$ & ro & $\cdot, 91$ & 10 &., 90 & 0 \\
\hline$\cdot, 90$ & &., 90 & צ r & •,Ar & 17 & .,9r & 7 \\
\hline \multirow[t]{4}{*}{$\cdot, 90$} & $r v$ & $\cdot, \wedge 9$ & $r V$ & $\cdot, 91$ & IV & $\cdot, 91$ & $v$ \\
\hline & & $\cdot, 91$ & rA & $\cdot, 91$ & 11 & $\cdot, 91$ & $\wedge$ \\
\hline & & . 94 & rq & $\cdot, \lambda)$ & 19 & $\cdot, 9 r$ & 9 \\
\hline & & $\cdot, \wedge)$ & $r$. & $\cdot, 97$ & $r$. & $\cdot, 91$ & 1. \\
\hline
\end{tabular}

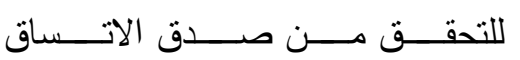

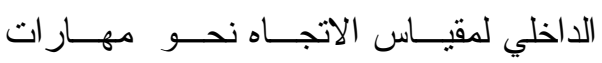

بظهر من الجـدول رقـم ( r ) أن

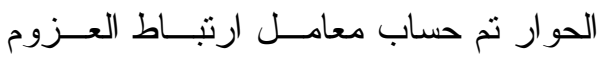

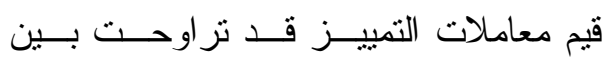

( بيرسون ) بين كل مفردة مــن مفــردات

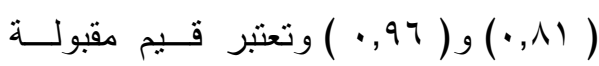

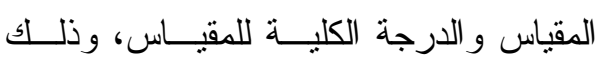

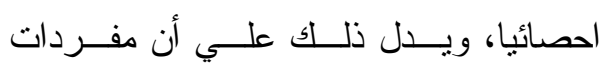

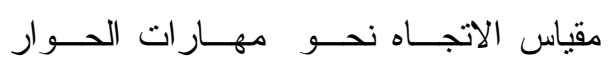

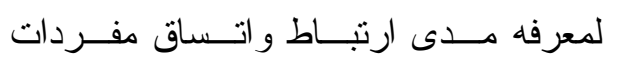

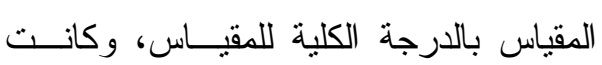

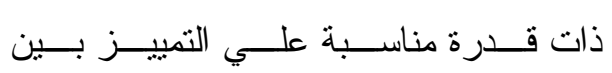

النتائج كما في الجدول التالي

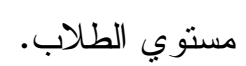

ج. صــــق الاتـسـاق الـــاخلب لمقيــاس

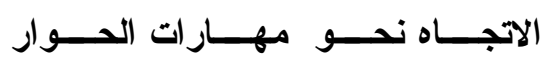

( صدق المحتوى ). 


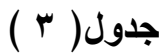

معاملات الارتباط بين مفردات مقياس الاتجاه نحو مهارات الحوار والارجة الكلية للمقياس

\begin{tabular}{|c|c|c|c|c|c|c|c|}
\hline معامل الارتباط & المفردة & معامل الارتباط & المفردة & معامل الارتباط & المفردة & معامل & المفردة \\
\hline$\cdot, \mathrm{V} r$ & r & $\cdot, 79$ & r & $\cdot, \times)$ & 11 & $\cdot, 79$ & 1 \\
\hline$\cdot, V \varepsilon$ & rr & $\cdot, v r$ & rr & $\cdot, 79$ & ir & $\cdot, 7 \wedge$ & $r$ \\
\hline$\cdot, \vee \wedge$ & rr & $\cdot, v_{0}$ & rr & $\cdot, V T$ & ir & $\cdot, \mathrm{V} \cdot$ & $r$ \\
\hline$\cdot, \uparrow \wedge$ & & $\cdot, 79$ & $r \leqslant$ & $\cdot, V T$ & $1 \varepsilon$ & $\cdot, 7 \wedge$ & $\varepsilon$ \\
\hline$\cdot, V r$ & o & $\cdot, V Y$ & ro & $\cdot, v_{0}$ & 10 & $\cdot, T V$ & 0 \\
\hline$\cdot, V \leq$ & q & $\cdot, V \leqslant$ & rq & $\cdot, 7 \wedge$ & 17 & $\cdot, V \leq$ & 7 \\
\hline \multirow[t]{4}{*}{$\cdot, V 4$} & $r v$ & $\cdot, 7 \Lambda$ & rV & $\cdot, V T$ & iv & $\cdot, v r$ & $v$ \\
\hline & & $\cdot, v_{0}$ & r^ & $\cdot, \vee \vee \leqslant$ & 11 & $\cdot, 79$ & $\wedge$ \\
\hline & & $\cdot, \uparrow \wedge$ & rq & $\cdot, V \cdot$ & 19 & $\cdot, V r$ & 9 \\
\hline & & $\cdot$ TV & r. & $\cdot, V_{1}$ & $r$. & $\cdot, V Y$ & 1. \\
\hline
\end{tabular}

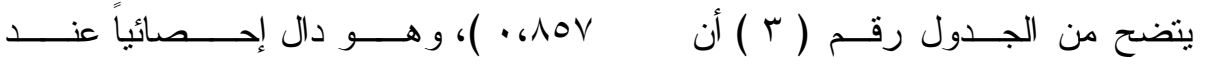

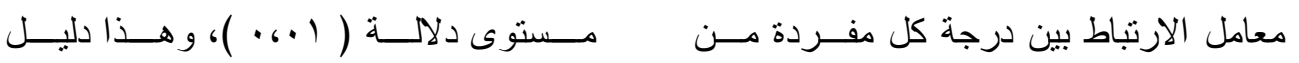

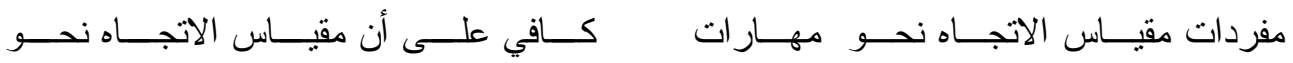

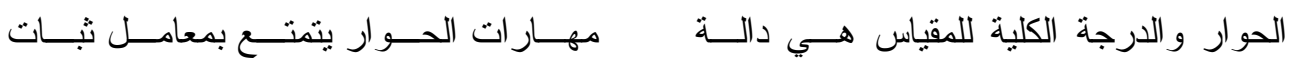

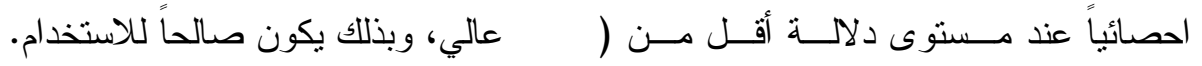

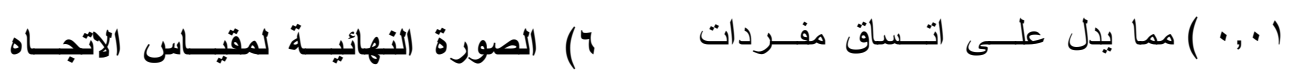

$$
\text { نحو مهارات الحوار: }
$$

تكونـــت مقيــاس مهــار ات الحـــوار

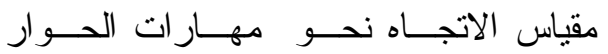
وصلاحيتها للتطبيق على عينة الدر اسة.

د. حساب ثبــات مقيــاس الاتجــاه نحسـو في صورته النهائية بعد إجــر اء التعـديلات

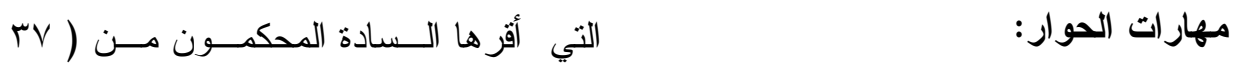

$$
\begin{aligned}
& \text { تـم حسـاب قيمــة معامــل ألفـــا - مفردة. }
\end{aligned}
$$

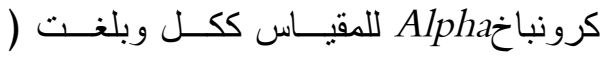


وتمنلت هذه الجو انــبـ فــي تتميــة:

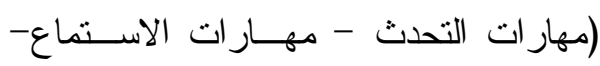

مهار ات خاصة بآداب الحوار). ع) الصياغة الإجر ائية للمكونات:

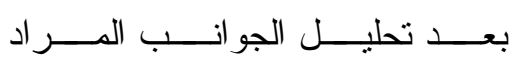

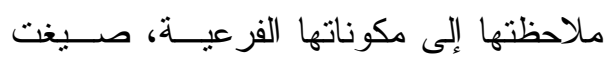

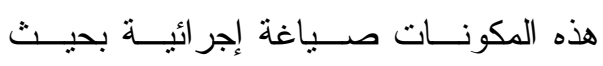

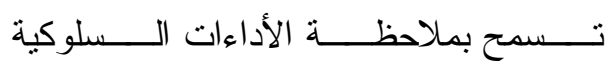

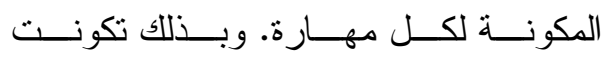

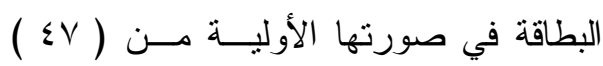

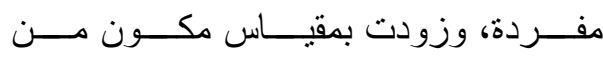

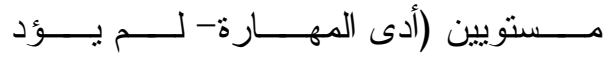

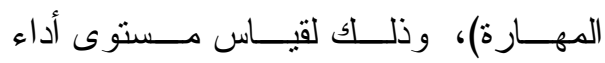
الطلاب الذين يوضعون تحـــت الملاحظـــة،

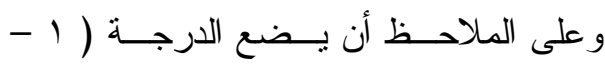

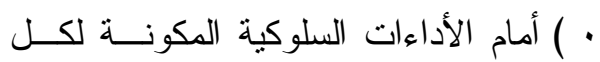

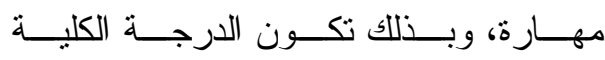
للبطاقة ( ) ع ) درجة. •) التحقق من صدق البطاقة: تم عرض البطاقــة فـي صــورتها الأولية علـى مجموعــة مــن المحكمــين

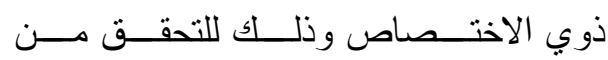

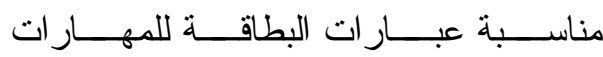
المنشودة، ومدى سلامة الــصياغة اللغويـــة

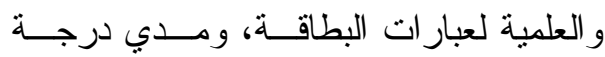

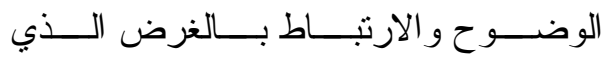

ب. بنــــاء بطاقة لــة ملاحظــــة مهــــارات

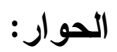

تم بناء بطاقة الملاحظة وفقـاً للإجـــر اءات التالية : - n

1. تحديد الهدف من بطاقة الملاحظة. r. الاطلاع علــى الدراســات الــسابقة

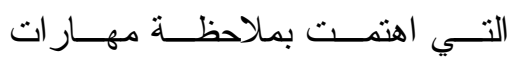
الحو ار. r. تحديد الجوانب المر اد ملاحظتها. ء. التحقق من صدق البطاقة. ه. الصورة النهائية لبطاقة الملاحظة. ( ) الهدف من بطاقة الملاحظة:

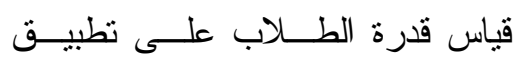

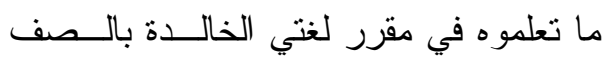

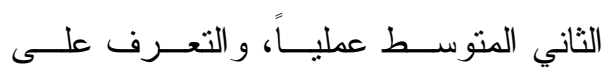

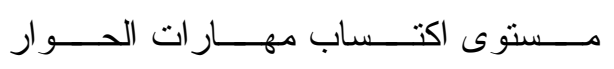
المرتبطة بهذه الدروس لدى الطلاب.

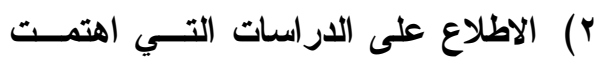

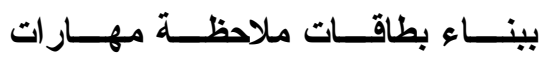

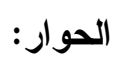

ومـــن هــــهـ الدراســــات :دراســــة

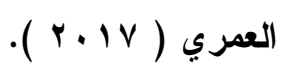

r) تحديد الجوانب المراد ملاحظتها: 
مقياس الاتجــاه نحـــو مهــار ات الحــوار، وبعد إجر اء التطبيق نم حساب ما يلي:

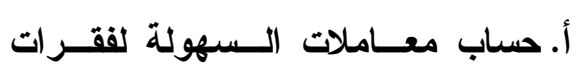

بطاقة الملاحظة:

بعد تطبيــق البطاقـــة علـــي العينـــة

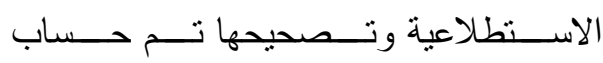

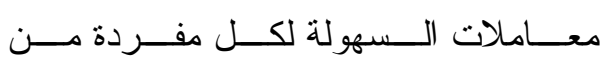

مفردات البطاقة، ويوضـح الجـدول التــالي

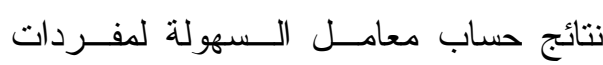

وضعت مــن أجلــه، بالإضـــافة إلــي أي إضافة أو حــف أو تعـديل بـــري الــــادة المحكمون ضرورة إضافتها إلــي البطاقـــة.

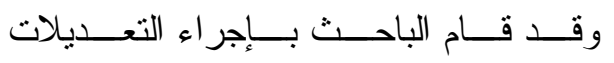

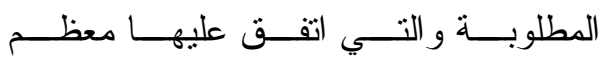
المحكمين وبذلك تصبح بطاقــة الملاحظــــة

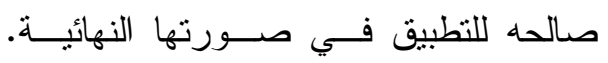
ملحق رقم (0) 7) التطبيق الاستطلاعي للبطاقة: تم تطبيق بطاقـــة الملاحظـــة علــي البطاقة.

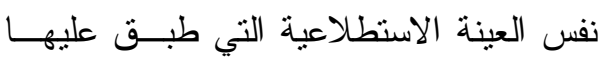
جدول ( ؛ )

قيم معاملات السهولة لمفردات بطاقة الملاحظة

\begin{tabular}{|c|c|c|c|c|c|c|c|}
\hline السهولة & المفردة & السهولة & المفردة & السهولة & المفردة & معامل & المفردة \\
\hline •, Or & $r v$ & $\cdot, 01$ & ro &., 09 & 14 &., 09 & 1 \\
\hline זT, • & rs & $\cdot, T \leqslant$ & Y & $\cdot, 70$ & $1 \varepsilon$ &., 00 & $r$ \\
\hline$\cdot, 71$ & $r q$ & $\cdot, v$ & $r V$ & $\cdot, \varepsilon r$ & 10 & $\cdot, 71$ & $r$ \\
\hline$\cdot, 01$ & 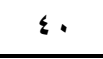 & $\cdot, 01$ & $r \wedge$ & •, or & 17 & $\cdot, 07$ & $\varepsilon$ \\
\hline • & $\leqslant 1$ & $\cdot, 7)$ & rq & $\cdot, V_{1}$ & IV & 0,70 & . \\
\hline •, $\leqslant 0$ & $\varepsilon r$ & $\cdot, 70$ & r. & זT, & 11 & Tr, & 7 \\
\hline$\cdot, 70$ & $\varepsilon r$ & $\cdot, 79$ & $\mu_{1}$ & $\cdot, \pi$ & 19 & $\cdot, 71$ & $\mathrm{v}$ \\
\hline$\cdot, 71$ & $\leqslant \varepsilon$ & $\cdot, V_{1}$ & $r r$ & $\cdot, \leqslant 1$ & $r$. & $\cdot, V_{1}$ & $\wedge$ \\
\hline$\cdot, 74$ & $\{0$ & . Or & $r \mu$ & $\cdot, 01$ & $r$ & , or & 9 \\
\hline$\cdot, \leqslant 0$ & $\leq 4$ & $\cdot, 01$ & $r \varepsilon$ & $\cdot, 07$ & rr & $\cdot, 01$ & 1. \\
\hline$\cdot, \varepsilon \cdot$ & $\leqslant V$ & $\cdot$, , 1 & ro & $\cdot, 71$ & r & $\cdot, 71$ & 11 \\
\hline & &., 07 & $r q$ & •, $\leq 7$ & $r \varepsilon$ & $\cdot, 71$ & Ir \\
\hline
\end{tabular}




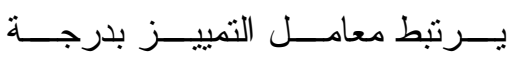

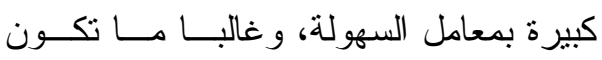

يظهر مــن الجـدول رقــم ( ع ) أن

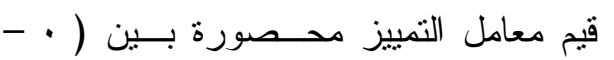

قيم معاملات السهولة قــــــراوحست بـــين

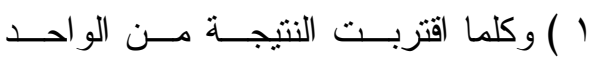

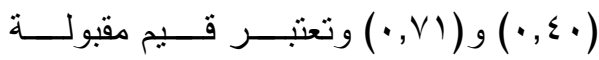

الـــصحيح كـــان الــسؤال أكتهــر تميــزاً.

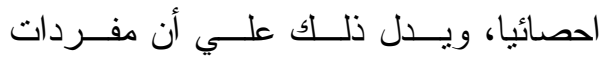

ويوضح الجــدول التـالي نتـائج حسـساب

بطاقة الملاحظة ذات مستوي مناسب.

· معامل التمييز

ب. حسـساب معــاملات التمييـز لفقــرات

بطاقة|لملاحظة :

جدول ( )

قيم معاملات التمييز لمفردات بطاقة الملاحظة

\begin{tabular}{|c|c|c|c|c|c|c|c|}
\hline معامل & المفردة & معامل & المفردة & معامل التمبيز & المفردة & معامل & المفردة \\
\hline • & $r v$ & . 94 & ro & $\cdot, 9$ & ir & $\cdot, \wedge 9$ & 1 \\
\hline$\cdot, 9 \leqslant$ & r & $\cdot, 9 \leqslant$ & r & $\cdot, 9 \leqslant$ & $1 \leq$ & $\cdot, 10$ & $r$ \\
\hline$\cdot, \wedge 9$ & rq & $\cdot 9$. & $r v$ & •,9r & 10 & $\cdot, \wedge 9$ & $r$ \\
\hline ., qr & $\varepsilon$. & $\cdot, \wedge \wedge$ & r^ & . & 17 & $\cdot, \wedge T$ & $\varepsilon$ \\
\hline$\cdot, \wedge 9$ & $\leqslant 1$ & $\cdot, 91$ & rq & $\cdot, \wedge \wedge$ & iv & $\cdot, 91$ & 0 \\
\hline$\cdot, 91$ & $\varepsilon r$ &., 90 & r. &., 91 & 11 & . 94 & 7 \\
\hline$\cdot, \wedge \vee$ & $\varepsilon r$ & $\cdot, \wedge \wedge$ & I &., 90 & 19 &., 9 . & v \\
\hline$\cdot, \wedge$ & $\varepsilon \varepsilon$ & $\cdot, 9 \leqslant$ & rr & $\cdot, 9 \leq$ & r. & $\cdot, 9 \varepsilon$ & $\wedge$ \\
\hline$\cdot, \wedge \vee$ & $\leqslant 0$ & $\cdot, 9$. & rr & $\cdot, \wedge \wedge$ & rI & . 94 & 9 \\
\hline$\cdot, 91$ & $\leq 7$ & $\cdot, \wedge q$ & ع & $\cdot, \wedge \vee$ & $r r$ & $\cdot, 91$ & 1. \\
\hline$\cdot, 90$ & $\leqslant V$ & . 94 & o & $\cdot, \wedge 0$ & $r r$ & $\cdot, \wedge 9$ & 11 \\
\hline & & $\cdot, \wedge 9$ & צ r & $\cdot, 90$ & $r \leq$ & $\cdot, \wedge \wedge$ & ir \\
\hline
\end{tabular}

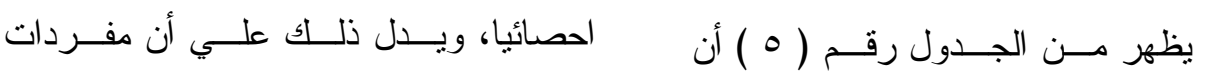

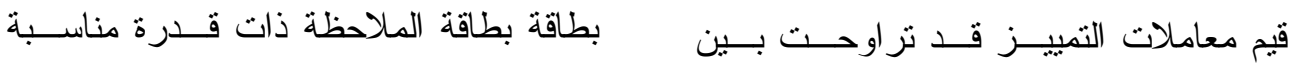

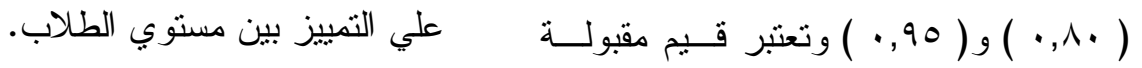


بعد من أبعاد بطاقـــة الملاحظـــة و الدرجــة

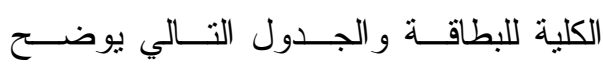

ج. صـــق الاتــساق الــــاخلي لبطاقـــة الملاحظة (صدق المحتوى).

تم حساب صدق الاتـساق الــداخلي ذلك ل Sinternal validity معامل ارتباط بيرســون بــين درجــة كــل

جدول(7)

صدق الاتساق الداخلي لبطاقة الملاحظة

\begin{tabular}{|c|c|c|}
\hline الدلالة & معامل الارتباط & أبعاد بطاقة الملاحظة \\
\hline دال عند مسنوى( ( , ·) & & مهارات التحدث \\
\hline دال عند مستوى( ( .,.) & $\cdot, 907$ & مهارات الاستماع \\
\hline دال عند مستوى( ( ,..) & .,914 & مهارات خاصة بآداب الحوار \\
\hline
\end{tabular}

الدرجة المستحقة لكل منهم ثـم حسبب

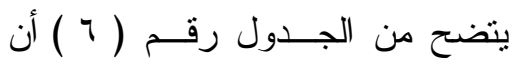

بعد ذلك نسبة الاتفــاق بــين الباحـــ معامل الارتباط بين درجة كـلـل بعــــــن مـن

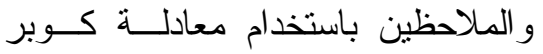
أبعاد بطاقــة الملاحظــــة و الدرجــــة الكليــــة (cooper)

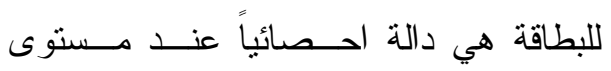
نسبة الاتفاق . . 1.

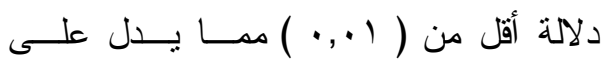
وكانت النتيجــة كمـــا يوضــــها الجـدول النالي:

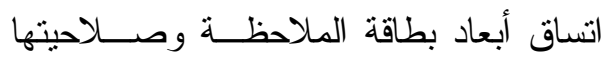
للتطبيق على عينة الدر اسة. د. حساب ثبات بطاقة الملاحظة:

$$
\begin{aligned}
& \text { قام الباحث مـــع اثتـين مــن الــزملاء }
\end{aligned}
$$

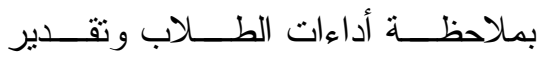




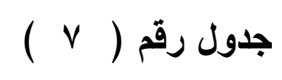

نسبة الاتفاق بين الباحث و الملاحظين لحساب ثبات بطاقة الملاحظة

\begin{tabular}{|c|c|c|c|}
\hline متوسط نسبة & بين الملاحظ الأول & بين الباحث والملاحظ الثاني & بين الباحث و الملاحظ \\
\hline$\% 9 r, 0$ & $\% q 4,0$ & $\% q r, \varepsilon$ & $\% 91,7$ \\
\hline
\end{tabular}

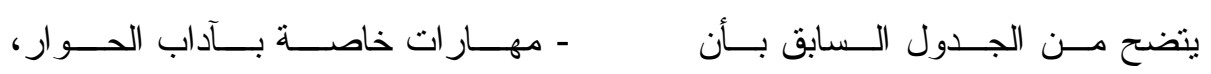

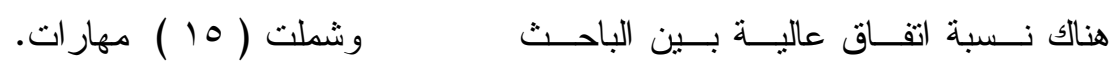

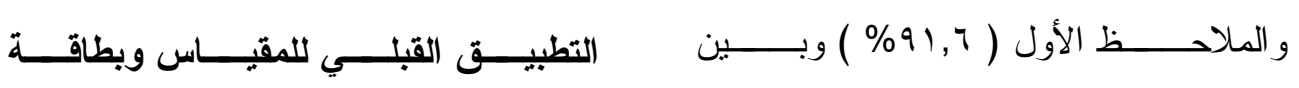

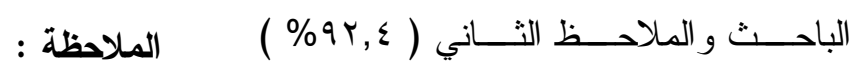

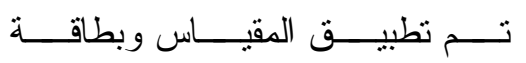

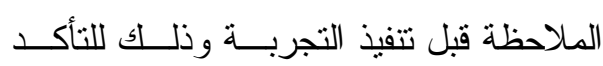
من تكافؤ وتجانس مجمو عة الدر اسة.

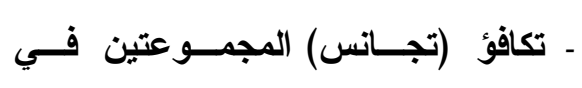
المقياس، وبطاقة الملاحظة:

للتحقق من عدم وجود فـروق بــين

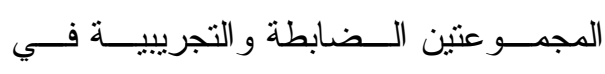

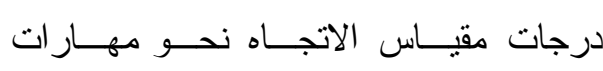

الحوار ودرجات بطاقة ملاحظـــة مهـــار ات مهـارت

$$
\text { الحوار، وفيما يلي النتائج: }
$$

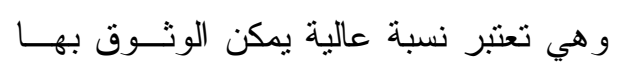
و الاعتماد عليها في الدراسة. ( الصورة النهائية لبطاقة الملاحظة:

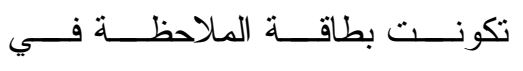

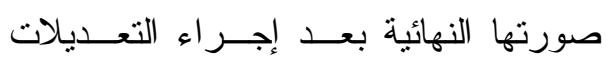
التي أقر ها الـسادة المحكمــون مــن ( ) مهارة كما يلى :

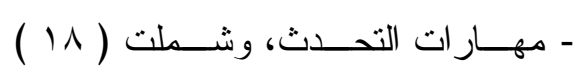

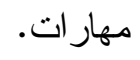

- مهار ات الاســتماع، وشــملت ( 1 ( ) مهار )

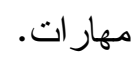


جدول ( ) ج ( )

نتائج الفروق بين المجموعتين التجريبية والضابطة

في القياس القبلي لمقياس الاتجاه نحو مهارات الحوار

\begin{tabular}{|c|c|c|c|c|c|c|}
\hline الالالة & $ت$ & د.د & الاحر اف المعياري & المتوسط & ن & المجموعة \\
\hline \multirow{2}{*}{ غير دالة } & \multirow{2}{*}{$\cdot, \cdot$. } & \multirow{2}{*}{$r \varepsilon$} & rו1, & $07, V T$ & 11 & الضابطة \\
\hline & & & 11,19 & 07,71 & 11 & التجرييية \\
\hline
\end{tabular}

جدول (9 )

نتائج الفروق بين المجموعتين التجريبية والضابطة

في درجات بطاقة ملاحظة مهار ات الحوار

\begin{tabular}{|c|c|c|c|c|c|c|}
\hline الالالة & 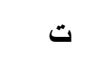 & ح.د & الاحر اف المعياري & المتوسط & ن & المجموعة \\
\hline$\cdot, \vee \backslash 4 \wedge$ & \multirow{2}{*}{$\cdot, r q \vee-$} & \multirow{2}{*}{$r \varepsilon$} & $1,9 \varepsilon$ & $I V, T V$ & 11 & الضابطة \\
\hline غير دالة & & & I, r & $1 v, 0$. & 11 & التجريبية \\
\hline
\end{tabular}

مهـــار ات الحـــــوار، وبطاقـــــة ملاحظـــــة

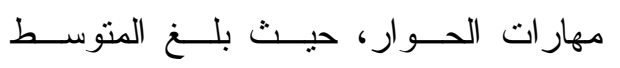

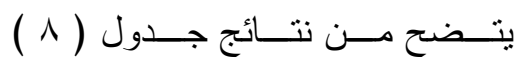

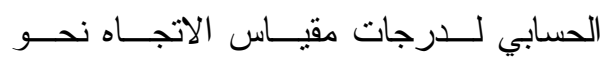

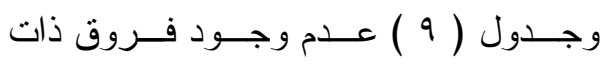

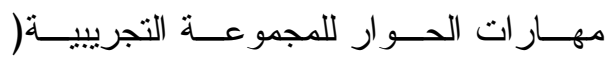

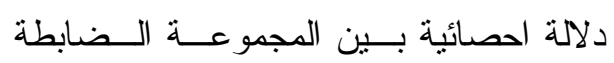

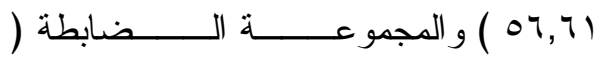

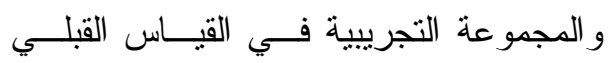

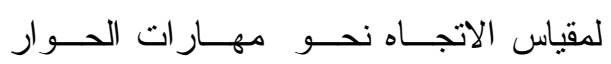

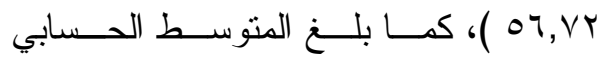

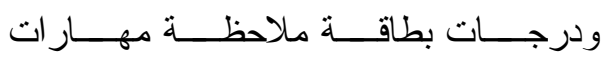

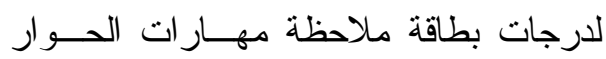

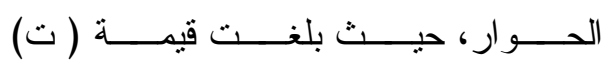

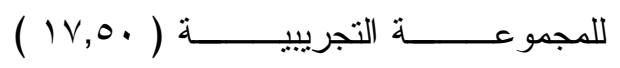

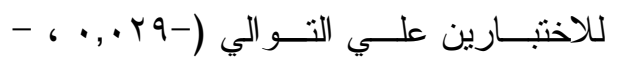

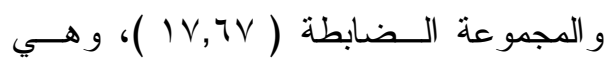

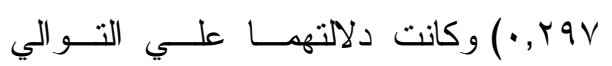

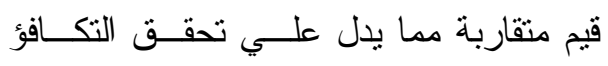

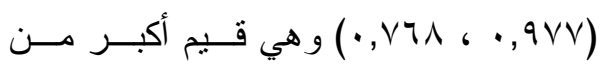
بين المجمو عتين.

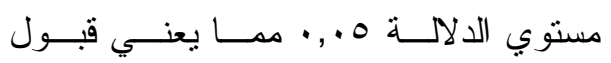

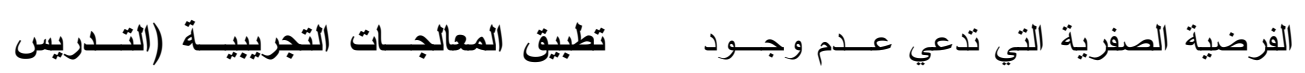

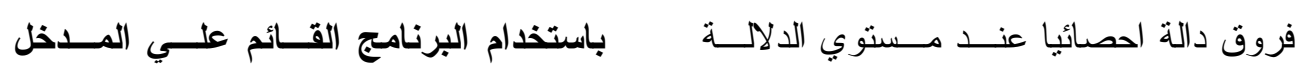

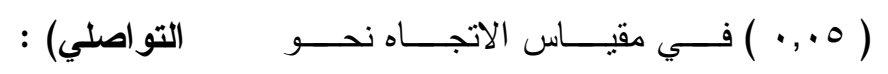




\section{عرض ومناقشهل تتائج الدراسل}

أولاً: عرض نتائج الدراسة: اختبار الفرض الأول:

نص على أنه: " توجد فــروق ذاول: ذات دلالـــة

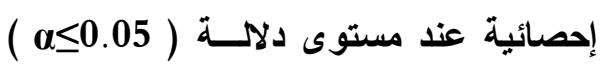
بين متوسطي درجات طــلاب المجموعـة المـة التجريبية التى درست باستخدام البرنــامتج القائم على المدخل التواصلي ودرجات طلاب لهي المجموعة الضابطة التى درست بالطريقــــة

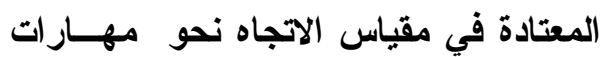
الحوار لصالح طلاب المجموعة التجريبية ". وللتحقق من صحة الفرضية تم حساب

المتوسطات الحسابية و الانحر افات المعيارية

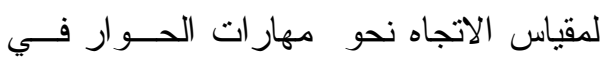
القياس البعدي للمجموعتين، التجريبية التـي التياهي درست باستخدام البرنامج القائم على المدخل التو اصلي و الضابطة التي درست بالطريقـــة

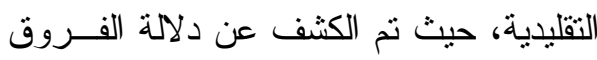

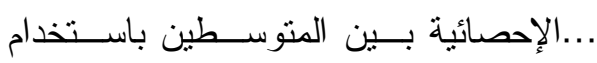

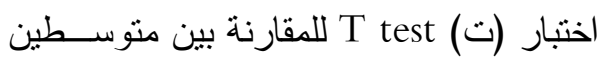

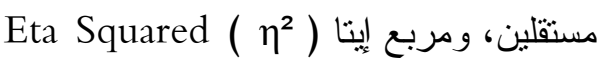
وجاءت النتائج كما تنين بجدول (· (1)

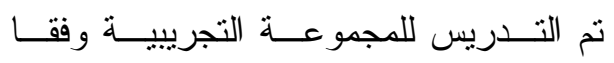

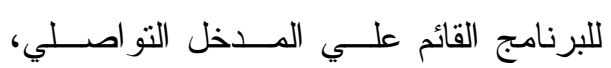

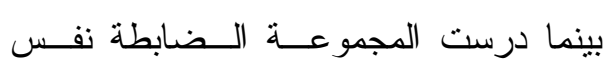

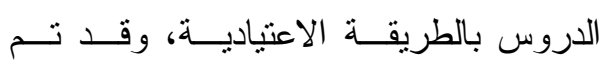

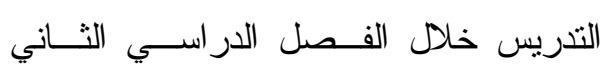

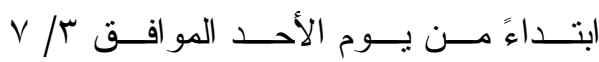

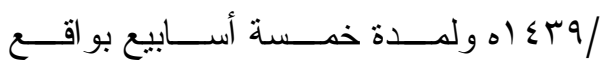
خمس أسبو عيا،.

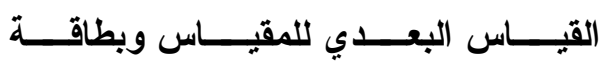
الملاحظة:

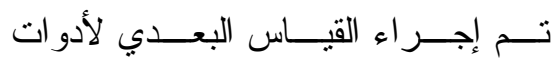

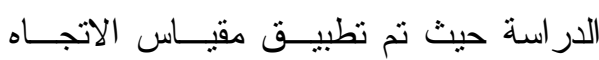

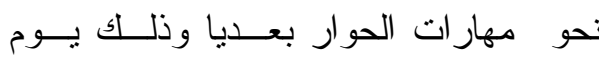

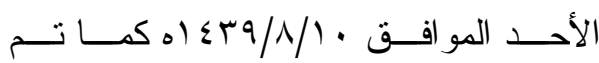
تطبيق بطاقة ملاحظـــة مهــار ات الحـــوار

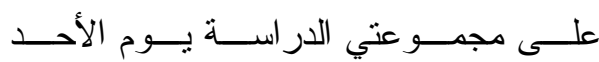

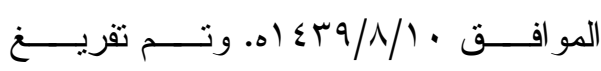

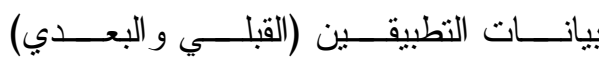

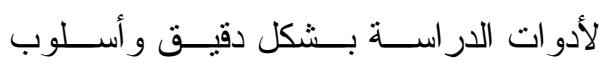

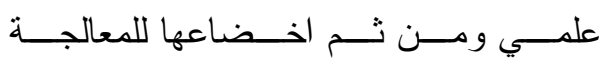

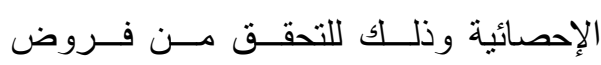
الدر اسة والإجابة عن أسئلتها. 
جدول (·)

نتائج الفروق بين المجموعتين التجريبية والضابطة

في القياس البعدي لمقياس الاتجاه نحو مهارات الحوار

\begin{tabular}{|c|c|c|c|c|c|c|c|}
\hline الإحصائية & قيمة ت & الحرية & الانحراف & الحتوسط الحسبي & العدد & المجموعة & مقياس الاتجاه \\
\hline \multirow[t]{2}{*}{$\cdot, \cdots$} & \multirow{2}{*}{19,100} & \multirow{2}{*}{$r \varepsilon$} & $r, \leqslant 1$ & I. Y, I & 11 & التجريبية & \multirow{2}{*}{ للارجة الكلية } \\
\hline & & & $0,4 \wedge$ & $V_{1}, V_{r}$ & 11 & الضابطة & \\
\hline
\end{tabular}

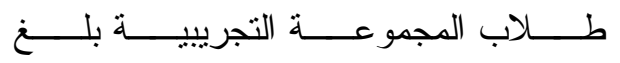

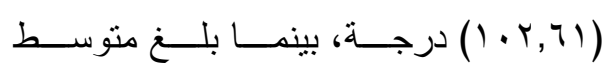

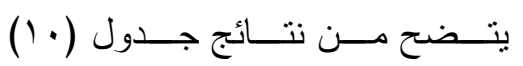

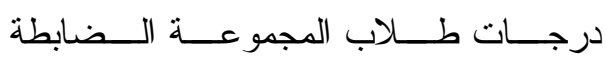

وجود فـروق ذات دلالـــة إحــصائية بــين

درجة، مما يــشير إلــي نجــاح (V), VY)

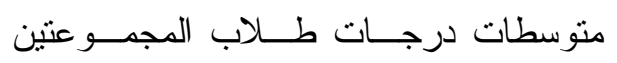

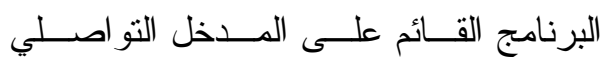

التجريبية و الضـابطة فــي القيــاس البعــدي في تتمية مهــار ات الحـــوار لـــدي طــلاب

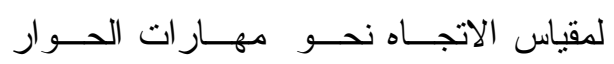
الصف الثاني المتوسط اختبار الفرض الثانى: الثئ

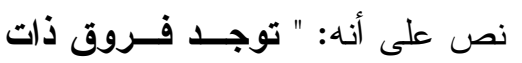

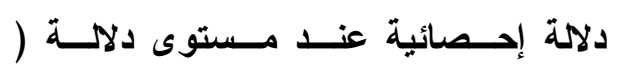

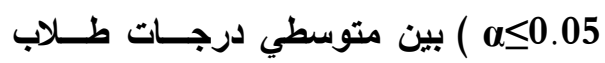
المجموعة التجريبية التى درست باستخدام

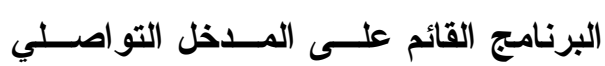
ودرجات طلاب المجموعة الــضابطة التـى درست بالطريقة المعتادة في بطاقة ملاحظة مهارات الحوار ككل وفي أبعادها الفرعيـة

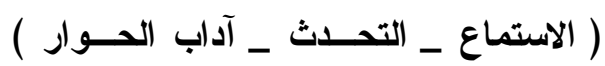

لصالح طلاب المجموعة التجريبية ".

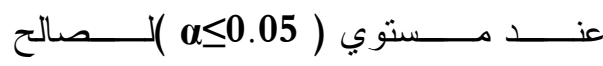

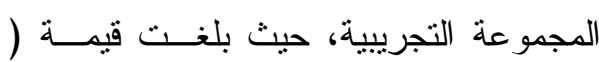

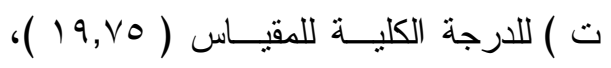

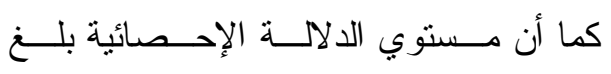

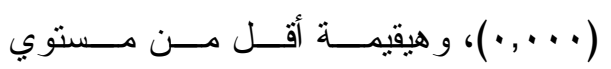

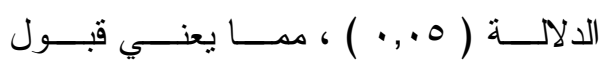
الفرضية البديلة التي تدعي وجــود فــروق

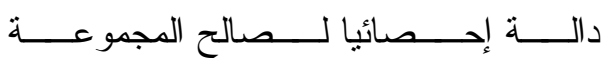
التجريبية ويعزي ذللك لاســتخدام البرنـــامج القائم علــى المــدخل التو اصــلـي، ويمكــن

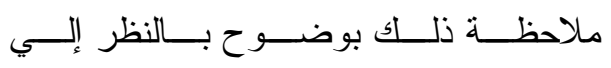
متوسط درجــات المجمــوعتين التجريبيــة و الضابطة حيث نجد أن متوســط درجـات 
بين المتوسطين باستخدام اختبــار (ت) thest إيتا Eta Squared(列

تبين بجدول ( I )
وللتحقق من صحة الفرضية نم حسساب

المتوسطات الحسابية و الانحر افات المعيارية

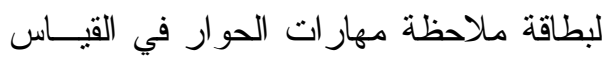

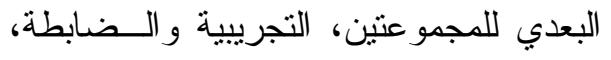
حيث تم الكثف عن دلالة الفروق الإحصائية

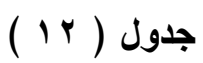

نتائج الفروق بين المجموعتين التجريبية والضابطة

في القياس البعدي لبطاقة ملاحظة مهارات الحوار

\begin{tabular}{|c|c|c|c|c|c|c|c|}
\hline الإحصائية & قيمة ت & لدرجات & الاحعراف & الحستوسط & العدد & المجموعة & بطاقة ملاحظة \\
\hline \multirow{2}{*}{$\cdot, \cdots$} & \multirow{2}{*}{1,01} & \multirow{2}{*}{$\Gamma$} & $1, r$. & $10,9 \leqslant$ & 11 & التجريبية & \multirow{2}{*}{ مهارات التحدث } \\
\hline & & & $r, . q$ & q,Ar & 11 & الضابطة & \\
\hline \multirow{2}{*}{$\cdot, \ldots$} & \multirow{2}{*}{$1 Y, .0$} & \multirow{2}{*}{$r \varepsilon$} & $\cdot, \mathrm{Vr}$ & $1 r, .0$ & 11 & التجريبية & \multirow{2}{*}{ مهارات الاستماع } \\
\hline & & & $1, \leqslant 9$ & $\Lambda, r r$ & 11 & الضابطة & \\
\hline \multirow{2}{*}{$\cdot, \cdots$} & \multirow{2}{*}{$1 r, 1}$. & \multirow{2}{*}{$\Gamma \xi$} &., 94 & $\mid r, \wedge \wedge$ & 11 & التجريبية & \multirow{2}{*}{ بآداب الحوار } \\
\hline & & & $1,7 \varepsilon$ & $\wedge, .$. & 11 & الضابطة & \\
\hline \multirow{2}{*}{$\cdot, \ldots$} & \multirow{2}{*}{$r \cdot, r^{\prime}$} & \multirow{2}{*}{$\Gamma \xi$} & 1,99 & $\varepsilon \curlyvee, \wedge \wedge$ & 11 & التجريبية & \multirow{2}{*}{ اللارجة الكلية } \\
\hline & & & $r, \wedge \vee$ & Y4,1 & 11 & الضابطة & \\
\hline
\end{tabular}

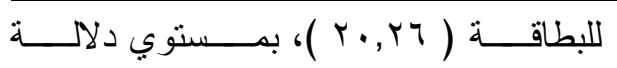

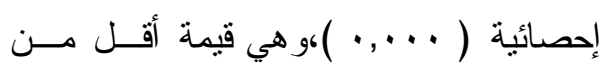

يتضح مسن نتـائج جـدول ( IT )

$$
\text { مستوي الدلالة ( ه.,. ) ). }
$$

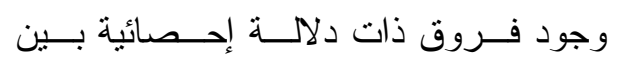

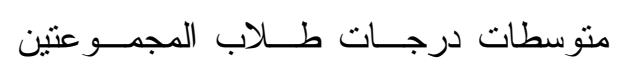

كمـــا بلغـــت قيمــة ( ت ) للأبعـــاد

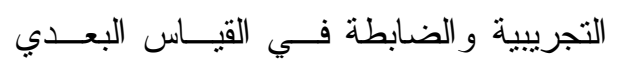

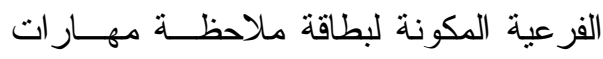

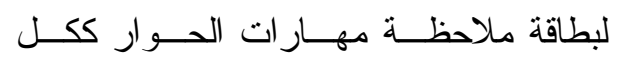

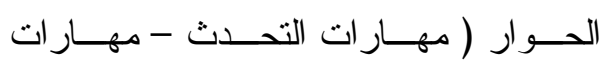

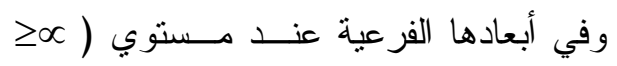

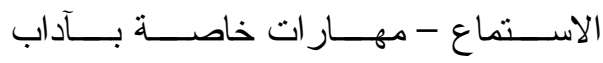

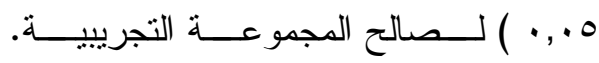

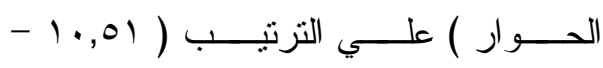


مـسـتوى دلالــــة ( $\alpha \leq 0.05$ ) بــــين

متوسطات درجات طــلاب المجموعـــة

التجريبية ودرجات طــلاب المجموعــة

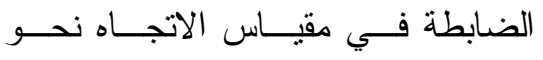

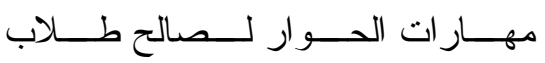

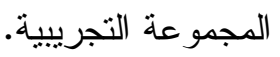

- ويتــضـح وجـــود فــروق ذات دلالـــة

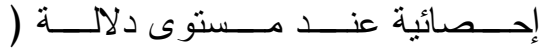

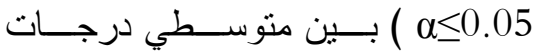

طلاب المجموعة التجريبيــة ودرجـــات

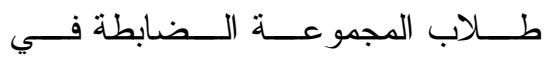
بطاقة ملاحظة مهار ات الحــوار ككـلـ وفي أبعادها الفرعية لــصالح طــلاب

المجمو عة التجريبية.

وقد تعــزى تلـــ النتــائج إلــى الأســبـاب

الآتية

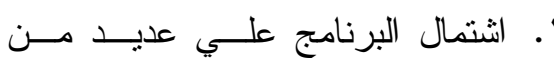

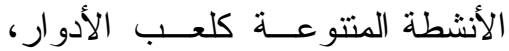

و إجر اء المناظر ات، و ابـــداء الــر أي

و التعبير عن وجهة النظـــر ، وتحليـلـل

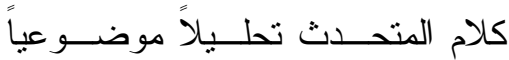

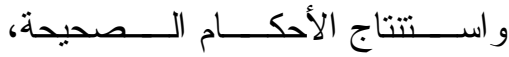

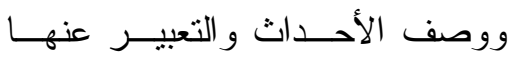

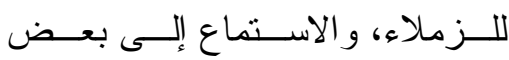

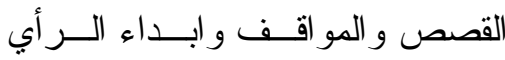

فيها وتشجيل مضمونها فـــي كر اســـة
0.

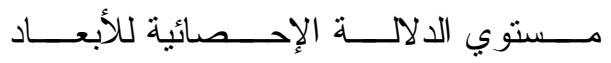

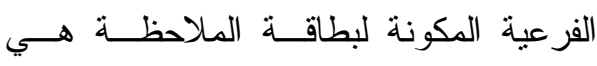

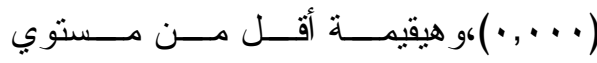

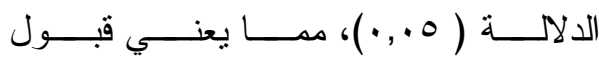
الفرضية البديلة التي تذعي وجــود فـروق دالة لصالح المجموعة التجريبية.

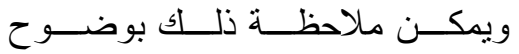

بالنظر إلي منتوسط درجــات المجمـــوعتين

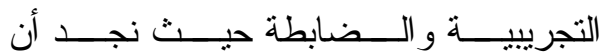
منوســـــ درجــــات طــــلاب المجمو عــــة التجريبية مرتفــع عــن متوســط درجـات المجموعة الــضابطة فــي الدرجـــة الكليـــة

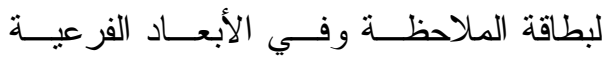
المكونـــة لهـــا، ممــــا يــثير إلـــي نجــــاح البرنامج القــائم علـــى المـــخل التو اصــلـي في تتمية مهــار ات الحـــوار لــدي طـلاب الصف الثاني المتوسط

\section{ثانيا: تفسير النتائج ومناقشتها:}

هدفت الدر اسـة الحاليــة إلـــي قيــاس فاعلية برنامج مقترح قــائم علــي المــــلـل التو اصلي في تتمية مهار ات الحـــوار لـــى

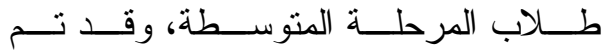
عرض نتــائج الدر اســـة، حيـــث ثوصــلـت الدر اسة الحالية إلى النتائج الآتية :

- يتضح مــن نتــائج الار اســة وجــود

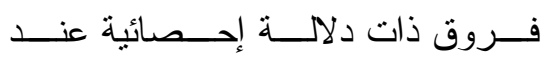


وضــــرورة الاســــتفادة منــــهـ وتعميمــــه،

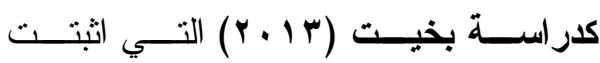

فاعلية استر اتيجية تعليمية مقترحسـة قائمـــة

على مدخل التو اصل اللغـــوي فــي تتميــة

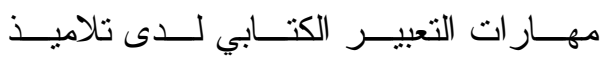

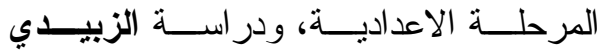

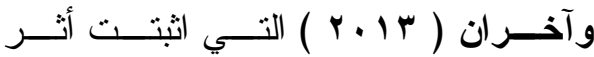
برنـــامج تعليمـــي قــائم علـــى المنـــــى التو اصلي في تحـسـين مهــار ات الاســتماع الناقد لدى طلبة الصف التاســع الأسـاسـي،

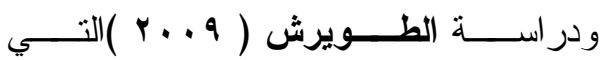
اثبتت أثــر اســتخدام المــــخل التواصــلي

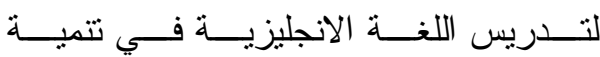

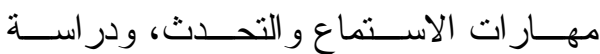
ســباتجلير ( spangler, 2009 ) التــي اثبتت أثز استخدام المدخل التو اصــلـي فـي تدريس اللغة في تتميــة مهـــار ات طلاقــة

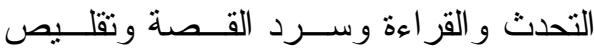
القلق مــن اللغـــة لــدى طــلاب المرحلـــة

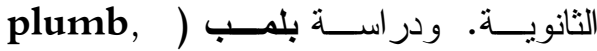

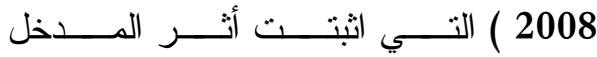
التو اصـــلي لتــدريس اللغــــة فـــي تحسـسين عملية اكتساب مهـــار ات اللغــــة الانجليزيـــة

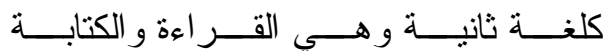
و التحدث و الاستماع ، و ذللك مــن وجهـــة نظر عينة مــن الطــلاب الــدوليين الــذين يدرسون في أحد برامج اللغـــة الانجليزيـــة
النشاط....؛ ممـــا أدى إلــــى اكتــساب الطلاب لمهار ات الحوار .

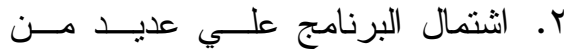
طـــرق التــدريس المنتوعـــة التـــي اتاحت الفرصة للطــلاب لممارســة الحوار في جو بسوده الأمــن والــود

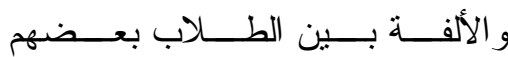

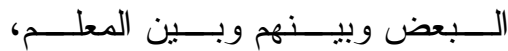

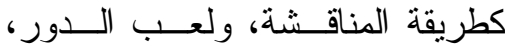
و الـــتـعلم التعــــاوني، و النمذجـــــة، ،

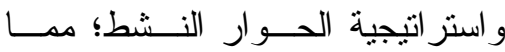
أدى إلى اكتساب الطـــلاب لمهــــار ات الحوار

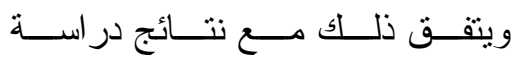

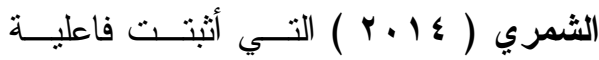
التدريس باســز اتيجية لعــب الأدوار فـي تتمية مهار ات الحــوار فــي مـــادة لغتــي

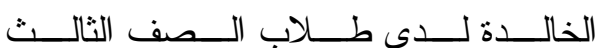

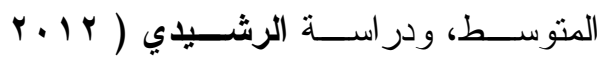
)التي أثبتت فاعلية تـــدربس اللغــــة العربيـــة بأسلوب الحوار في تحصبل طلبــة الـصف التاســـــع و وتفكيــــر هم الاســــتقر ائي بدولـــــة الكويت.

كما تتفــق نتــائج الدر اســـة الحاليــة مـــع معظـــم مــــا توصـــلت إلبــــه نتـــائج

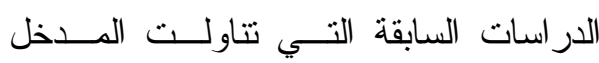

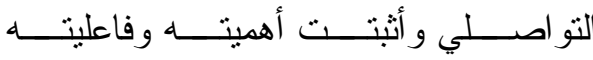




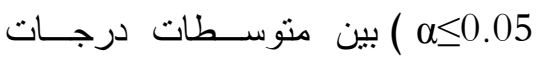

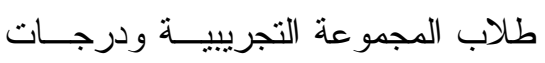

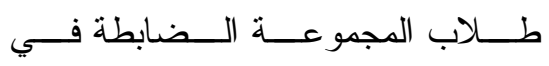

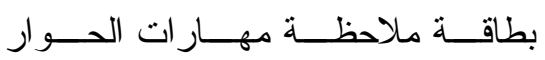

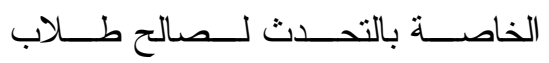

$$
\begin{aligned}
& \text { المجمو عة التجريبية. }
\end{aligned}
$$

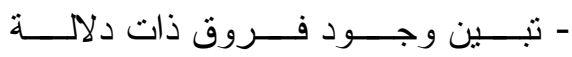

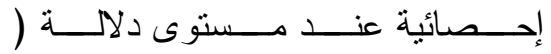

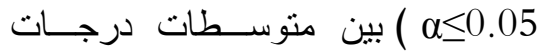

$$
\begin{aligned}
& \text { طلاب المجموعة التجريبيــة ودرجــات }
\end{aligned}
$$

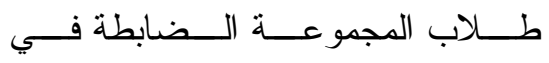

$$
\begin{aligned}
& \text { بطاقـــة ملاحظــــة مهـــار ات الحــــوار }
\end{aligned}
$$

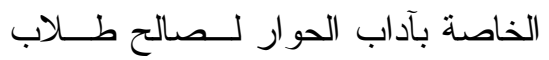$$
\text { المجمو عة التجريبية. }
$$

- تبين وجود فروق دالة إحــصائيا عنـــد

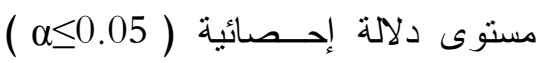
بــين منوســــات درجــــات طـــلاب

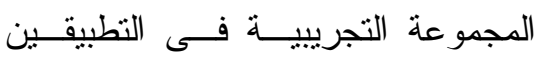

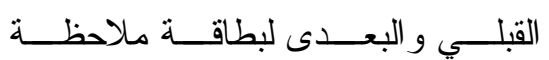

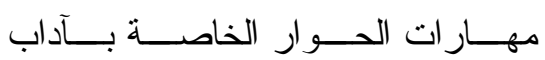
الحوار لصالح التطبيق البعدى.

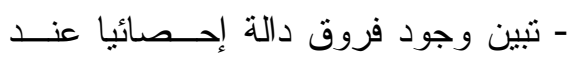

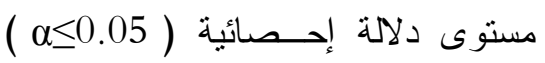

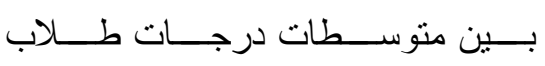

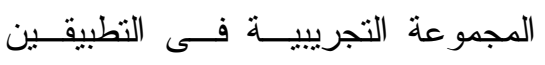

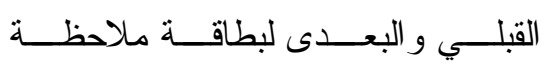

للأغـــــر اض الأكاديميـــــــ EAP بكنـــــــا.

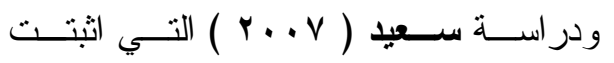

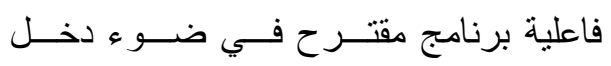

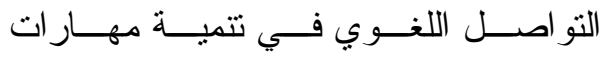

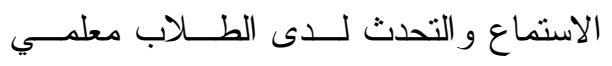

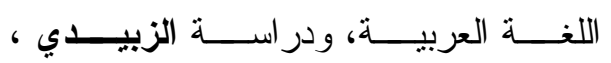

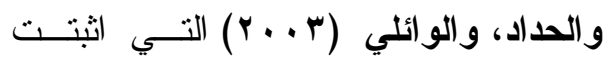

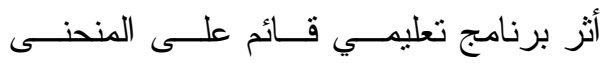

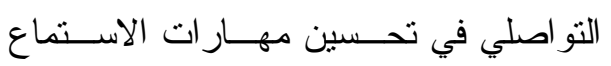

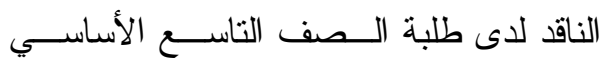
ملخص النتائج والتوصيات والثقترحات أولاً : ملخص نتائج الدراسة :

أسفرت نتائج الار اسة الحاليــة عـنـ

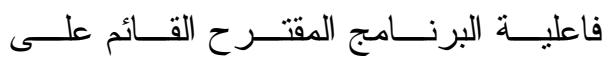

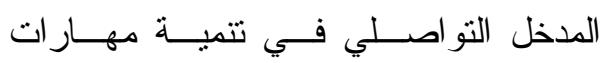

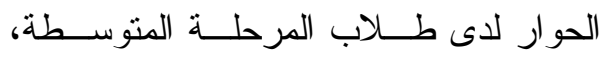
وذلك علي النحو التالي:

- تبـــين وجــــود فــروق ذات دلالــــة

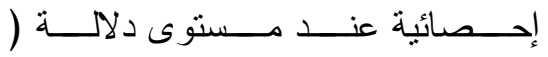

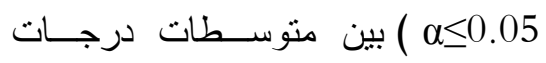

طلاب المجمو عة التجريييــة ودرجــات

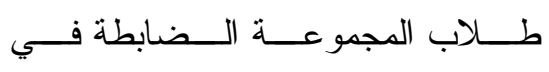
مقياس الاتجاه نحو مهـــارات الحـــوار لصالح طلاب المجموعة التجريبية.

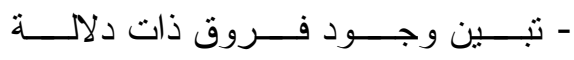

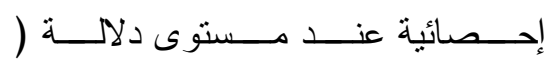




$$
\begin{aligned}
& \text { ومعلميها لتعريفهم بمزايــا اســتخدام }
\end{aligned}
$$

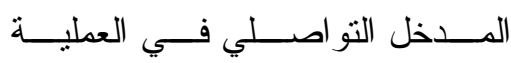

$$
\begin{aligned}
& \text { التعليمية وكيفية تطبيقه فـي تـدريس } \\
& \text { اللغة العربية. } \\
& \text { r. اســتخدام المـــخل التواصــلي فــي }
\end{aligned}
$$

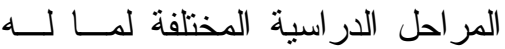

$$
\begin{aligned}
& \text { مــن فاعليـــة و اضـــــة فـــي تتميـــة } \\
& \text { مهار ات الحوار لدي الطلاب. }
\end{aligned}
$$$$
\text { ثالثاً : المقترحات : }
$$$$
\text { في ضوء النتائج التي تــم التوصـلـ }
$$$$
\text { إليها يقترح الباحث إجر اء در اســات حــول }
$$$$
\text { الآتي: }
$$$$
\text { 1. إجر اء در اسة مقارنـــة بــين فاعليــة }
$$

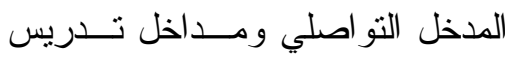

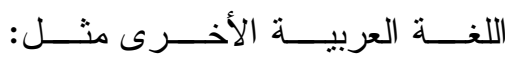

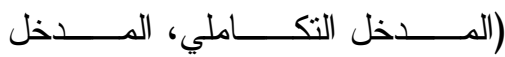$$
\text { المهاري، المــــخل الــوظيفي) فـي }
$$$$
\text { تتمية مهارات الحوار لاي الطــلاب }
$$$$
\text { بمختلف المر احل الدراسية. }
$$

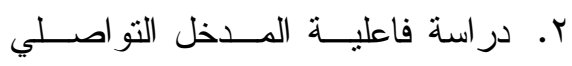

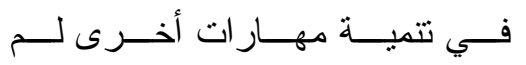

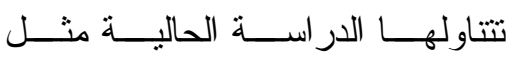

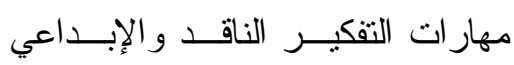$$
\text { ومستويات الفهم القر ائي. }
$$

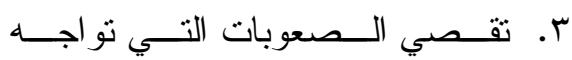

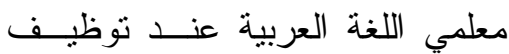

مهار ات الحوار ككل لــصالح التطبيــق

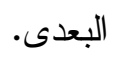
- كما تنين وجــود حجــم تــأثنير كبيـر

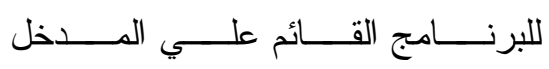
التو اصلي في تتمية مهـــار ات الحـــوار

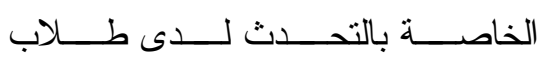

$$
\text { المرحلة المتوسطة. }
$$

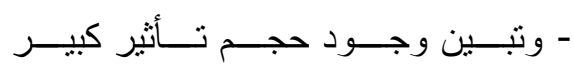

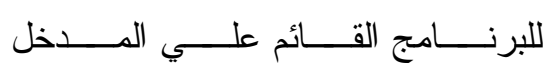

التو اصلي في تتمية مهــار ات الحـــوار

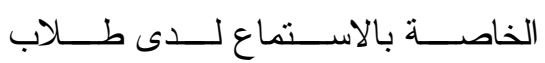

المرحلة المتوسطة.

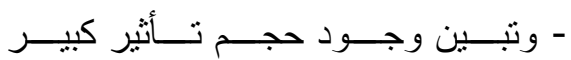

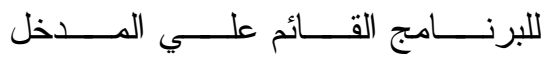

التو اصلي في تتمية مهــار ات الحـــوار

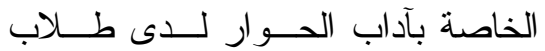

$$
\text { المرحلة المتوسطة. }
$$

\section{ثانياً : التوصيات :}

في ضو ء النتــائج الــسابقة خلــصت هذه الدر اسة إلي التوصيات الآتية :

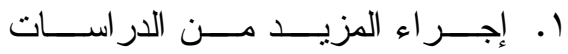

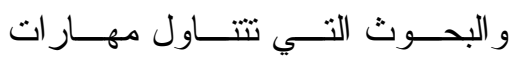

الحوار وسبل تتميتها لــدي الطــلاب بمختلف المر احل التعليمية.

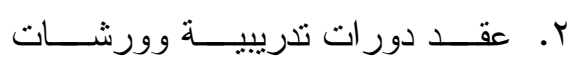

عمل لتدريب مشرفي اللغة العربيــة 
الثانوية، الرياض، مركز الملك عبدالعزيز للحوار الوطني. مكتبة الملك فهر الوطنية. - البجة، عبدالفتاح حسن. ( . . . ب ) أصول

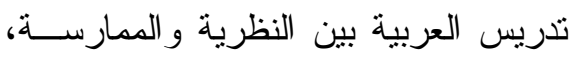
عمان، دار الفكر

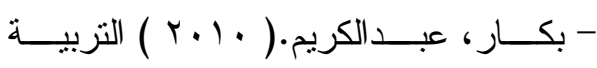
بالحوار، الرياض. مركز الملك عبدالعزيز للحوار الوطني، مكتبة الملك فهر الوطنية. - الباهي، حسن.( ع . . r ) الحوار ومنهجية التفكير النقـــي، المغـــرب، دار افريقيــــا

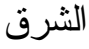

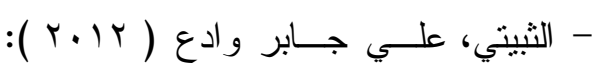
الحوار في ضو ء الكتاب و السنة ، الجمعية المصرية للقر اءة والمعرفة، مجلة القر اءة

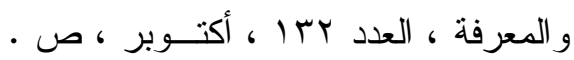
rVq - r

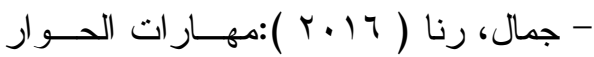

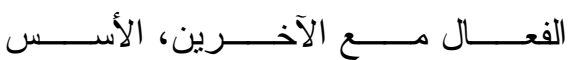
و الاستر اتيجيات، الأردن، عمان ، دار من الأن الاسن

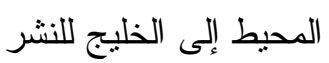

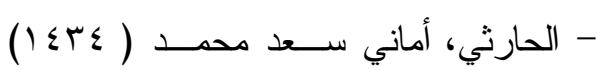
فاعلية استخدام استر اتيجيات مختارة فـي التي تدريس مادة الحديث و الثقافة الإســلامية لتتمية الوعي بمفاهيم التقافــة الإســلامية الإسية

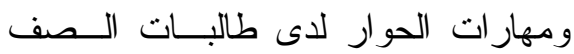
الأول الثانوي بمدينة مكة المكرمة. رسالة
المدخل الاتصالي في تــدريس اللغـــة

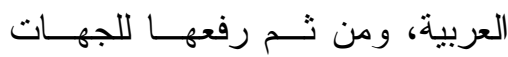
المختصة لمحاولة تذليلها.

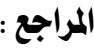

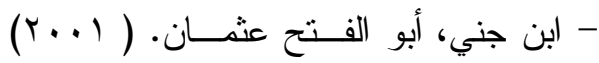

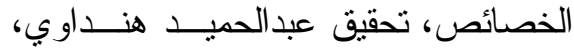
بيروت ، دار الكتب العلمية .

- ابن منظور ، جمال الدين محمد. ( 997 ) لسان العرب. بيروت، دارصار .

- أحمد، ســناء محمـد حسسن. ( • ( ) )

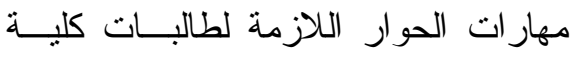

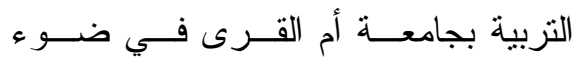
متغير ات العصر و مستجداته و قياس مدى ني تمكنهم من تلكك المهار ات، الجمعية العربية للقر اءة و المعرفة، مجلة القر اءة و المعرفة ،

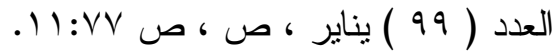
- الأصفهاني، الر اغب. ( I99V ) معجـ

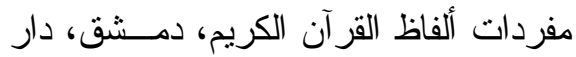
القلم للنشر و النوزيع. - أنيس، ابـــر اهيم و آخــرون. ( I I ا ل المعجـــم الوســـــ، القـــاهرة، دار الفكـر

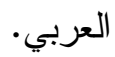

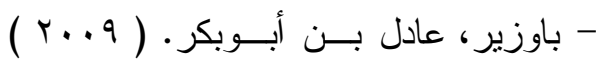
دور معلم التزبية الإســلامية فــي تتميــة قدرات الحوار الوطني لدى طلبة المرحلة 
- الرشيدي، أحمد عنيزان. ( ب ا • ب) فاعلية تدريس اللغة العربية بأسلوب الحوار فــي الحئ تحصيل طلبة الصف التاســع و تقكيـر هم الاستقرائي ، رسالة ماجستير غير منشورة

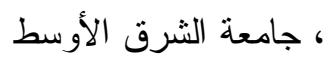

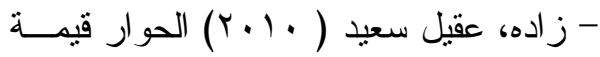
حضارية، عمــان، دار النفــائس للنـشر و التوزيع

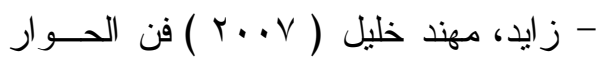
و الاقناع، عمان، دار النفائس مهند

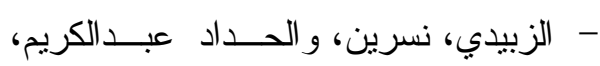

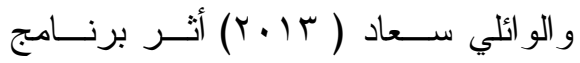

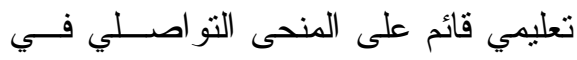
تحسين مهار ات الاستماع الناقد لدى طلبـــة الصف التاسع الأساسي، المجلة الأردنيـــة

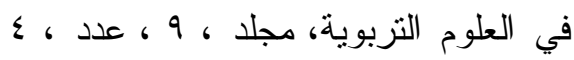
؛ - زريفات، وليــد فــلاح (

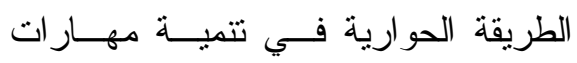
التحدث و التفكير الناقد لدى طلاب الصف العاشر الأساسي في الأردن رسالة دكتور اة

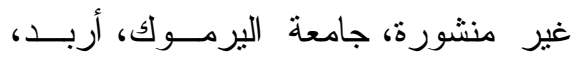
الأردن

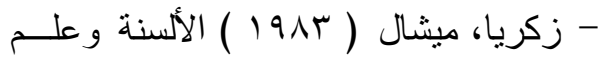
اللغة الحديث، المباديء و الأعلام، بيروت
دكتور اه غبر منشورة، كلية التزبية، جامعة أم القرى، مكة المكرمة

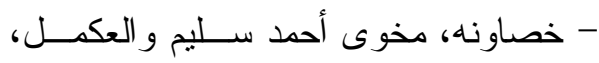

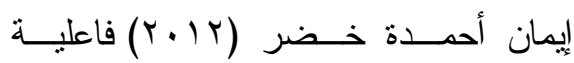

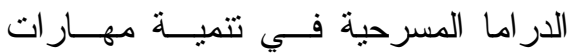

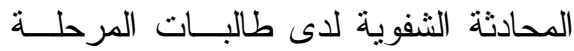

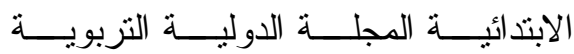
المتخصصة، المجلد (1) العدد (ع) أيسـار ص.ص r.0:11r

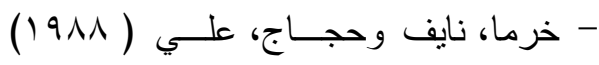

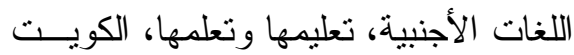
سلسلة عالم المعرفة، العدد، يونيو

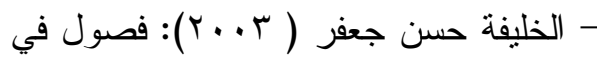
تدريس اللغة العربية ( ابتدائي _ متوسـط _ ـ ثانوي) الرياض، مكتبة الرشد

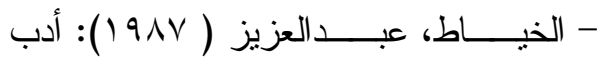
الحوار، عمان. منشورات وزارة الأوقاف

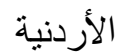
- الخولي، محمد علي ( بر 191 ) : أســاليب تدريس اللغة العربية القاهرة، عالم الكتب

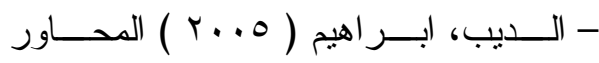
المحترف: آداب ومهــار ات القــاهرة، أم لم الم القرى للتزجمة و النشر و التوزيع - الرازي،محمد بن أببي بكر. (

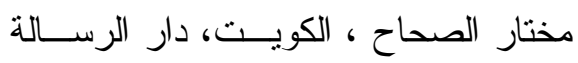
للنشر و التوزيع 


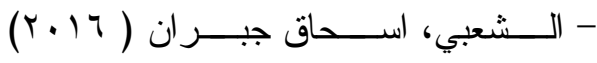

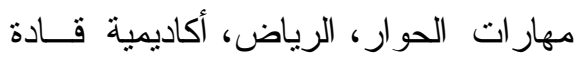

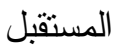

- الشريف، فهذ ماجد فهد الفعـر (1) (1) فاعلية المدخل التو اصلي لتــدريس اللغـــة الانجليزية في تتمية مهــارتي الاســتماع

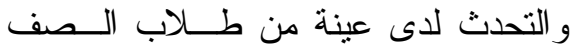
الأول الثانوي، الجمعية المعرفية للقـــراءة و المعرفة، مجلة القر اءة و المعرفة، العـدد

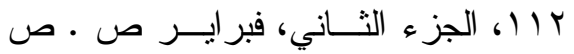
$11 \cdot-v$.

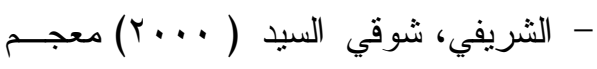

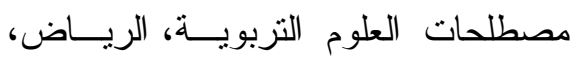

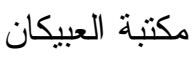

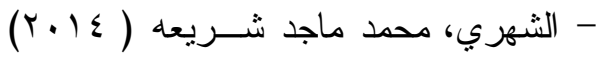
فاعلية استخدام استر اتيجية لعــب الأدوار

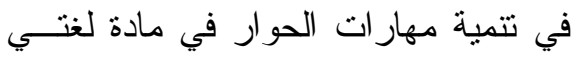
لاى طلاب الصف الثالث المتوسط بحفـر الباطن، رسالة ماجستير، كليــة التزبيــة، جامعة أم القرى، مكة المكرمة

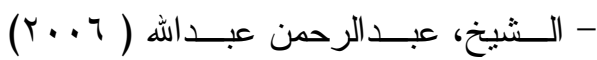
الحوار مع المخالف، الرياض، دار المريخ

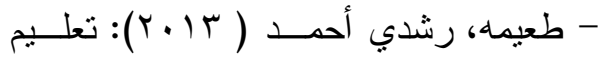
اللغة اتصالياً بين المناهج و الاستر اتيجيات
المؤسسة الجامعيــة للار اســات و النــشر و التوزيع

- الزمخشري، أبي القاسم محمود ( (... أساس البلاغة، دار الفكر، بيروت لبنان

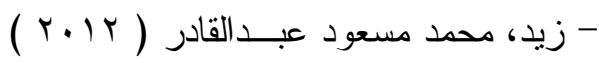
برنامج قائم على المو اقف الحوارية لتتمية

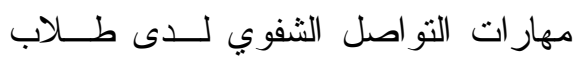
المرحلة الثانوية العامة فــي مــادة اللغــــة

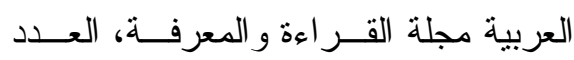

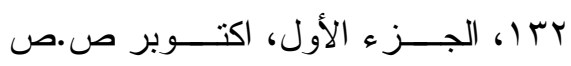
$1 T V-11 \mathrm{~V}$

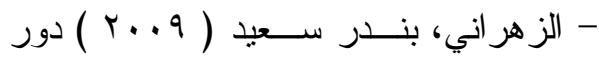

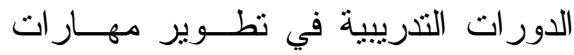

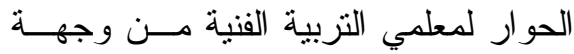
نظر هم رسالة ماجستير غير منشورة، كلية التزبية، جامعة أم القرى، مكة

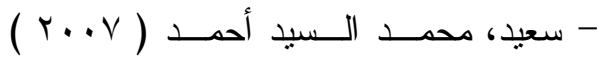
برنامج مقتر ح لتنمية مهــار ات الاســتماع و التحدث لدى الطلاب معلمي اللغة العربية في ضوء مدخل التواصل اللغوي، مجلــــة

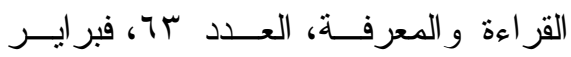
ص.ص

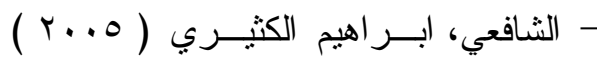

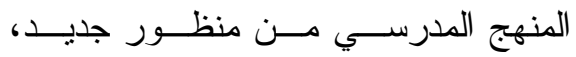
الرياض، مكتبة العبيكان 
في تدريس اللغة العربية لتتمية مهــارات التعبير الكتابي لدى العــر اقيين النـاطقين بالكردية، مجلة العلوم التربوية، مجلد بr بـ، عدد r، الجزء الثاني، بوليو - العبيد، ابر اهيم عبداله ( 9 ( . . ) ): تعزيز

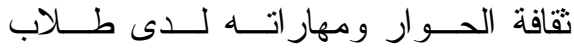
المرحلة، الدو اعي و المبرر ات و الأساليب، الرياض، مركز الملك عبدالعزيز للحسـوار ولهئ

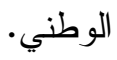

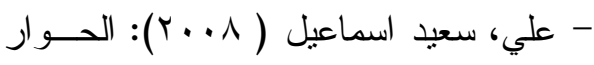
منهجاً وثقافة القاهرة، دار السلام

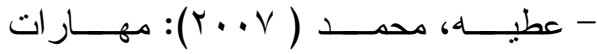
الاتصال اللغوي وتعليمهــا، عدــان، دار المناهج للنشر و النوزيع.

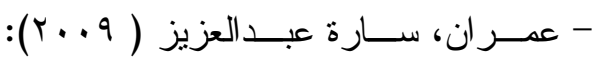
فاعلية برنامج في الأنشطة اللغوية لتتميــة

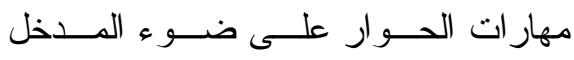
التو اصلي لدى طلاب شعبة اللغة العربيـــة بكليات التزبية، رســالة ماجـسنتير غيــر

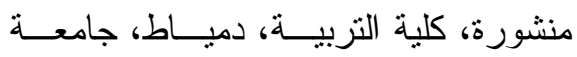

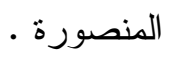

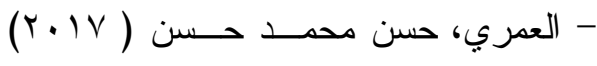
أثز استخدام الصفوف الافتز اضية في تتمية

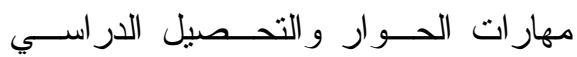
و الاتجاه نحو المقرر لــــى طلبـــة كليـــة الثريعة في جامعة القصيم، مجلة جامعــة

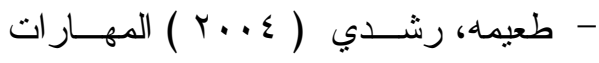

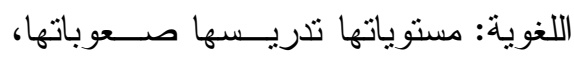
القاهرة، دار الفكر العربي. - طعيمه، رشدي أحمد، ومناع، محمد السيد

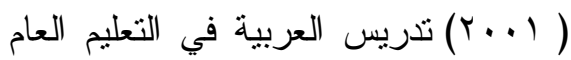
( نظريات وتجارب ) القاهرة، دار الفكـر العربي

- طعيمه، رشدي أحمــد ( 1919 ) تعلــيم

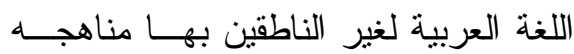

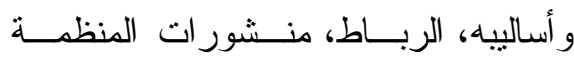

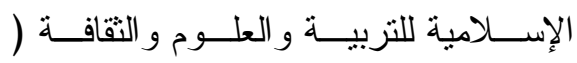
(إيسيسو )

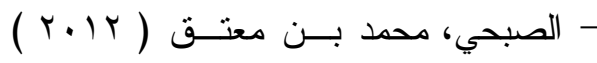
فاعلية برنامج تدريبي مقترح على تتميـة

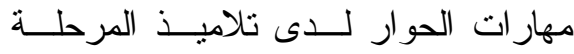
المتوسطة في المدينــة المنــورة، رســالة ماجستير غير منـشورة، كليــة التزبيــة، جامعة طيبه، المدينة المنورة.

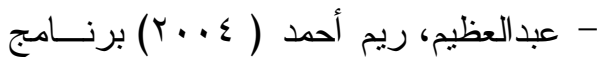
مقتر ح لتتمية مهـــار ات الحـــوار باللغــــة

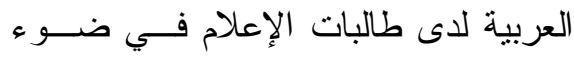
مدخل التو اصل اللغوي رسالة ماجسـتير غير منشورة، كلية البنات، جامعسـة عــين شمس - عبد المنعم، محمد صابر ( 10 (ب) فاعلية برنامج مقتر ح قائم على المدخل التو اصلي 
در اسات في المناهج و طرق التــدريس ،

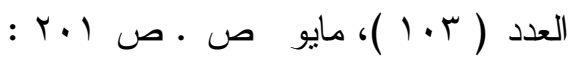
$r \leq \varepsilon$

- القرطبي، محمــد بـن أحمــد ( 997 (1): الجامع لأحكام القرآن الكريم، القاهرة، دار الحديث للنشر و النوزيع.

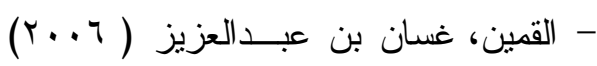
أدب الحوار في الإســـلام، بيــروت، دار

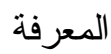

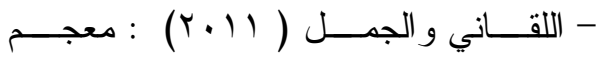
المصطلحات التربوية المعرفة، القــاهرة،

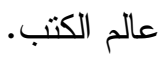

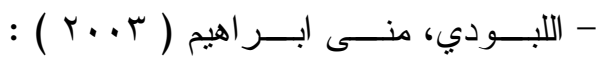

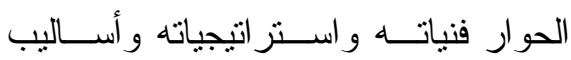

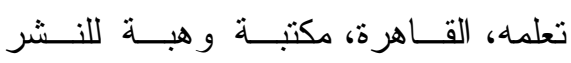

$$
\text { و التوزيع. }
$$

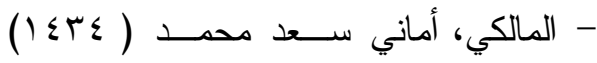
فاعليــة اســتخدام اســـتر اتيجيات الــتـعلم

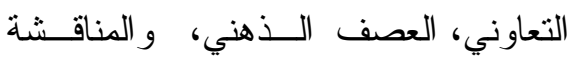
النشطة في تتمية الوعي بمفــاهيم الثقافـــة الإسلامية ومهار ات الحوار لدى طالبــات الصف الأول الثانوي بمدينة مكة المكرمة،

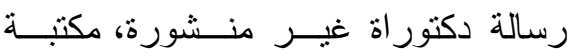

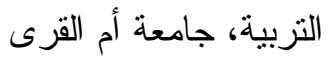
- المالكي ، عبدالرحمن عبداله ( م. . ب ) : مهار ات التربية الإسلامية سلـسلة كتــاب
القدس المفتوحــة للأبحـــاث و الدر اســات التربوية و النفسية، مجلد $7 ،$

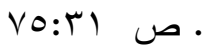

- عوض، أحمد عبده ( ( .... تعليم اللغة العربية، دراسة مسحية نقديــة

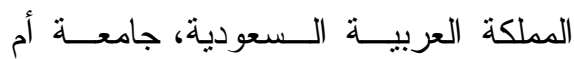
القرى، معهد البحــوث العلميــة، مركــز البحوث التربوية و النفسية، مكة المكرمة. - العيسوي، جمال مصطفى و موسى، محمد

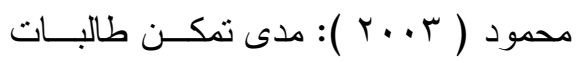

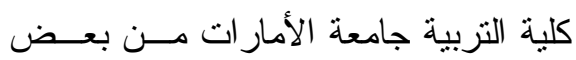
مهار ات الاتصـال الثفهي، مجلة القـــر اءة

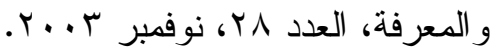

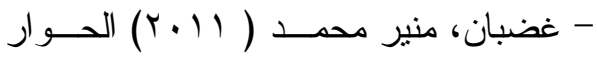

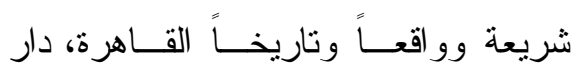

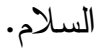

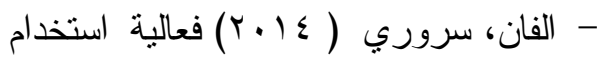

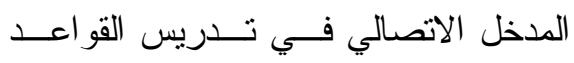

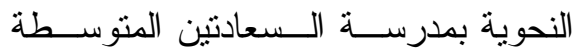
الإسلامية، بحث مقدم إلى جامعة شــريف بعـيف هداية الله الإسلامية، جاكرتا. كلية التربية - قاسم، محمد جابر و النقبي، علي خلفــان.

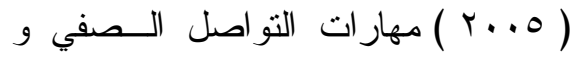
مستوى أدائها لاى معلمي اللغــــة العربيـــة و العلوم بالمرحلــــة الابتدائيـــة، الجمعيــــة

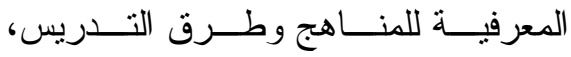


- مدكور، علي أحمد ( (r... ) تـدريس

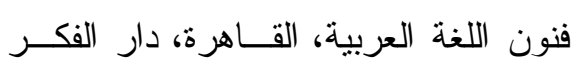

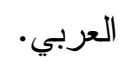

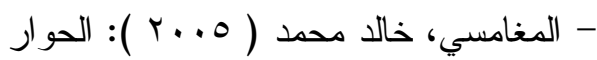
آدابه وتطبيقاته فـــي التربيـــة الإســلامية

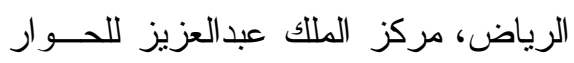

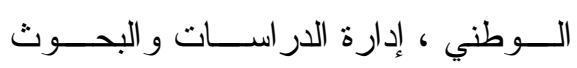
و النشر.

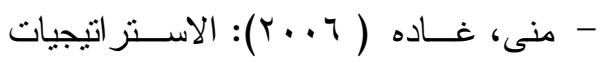

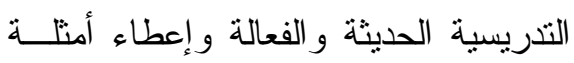

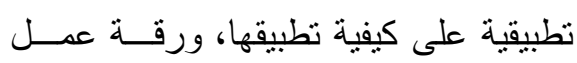
مقدمة إلى، جامعة المجمعة.

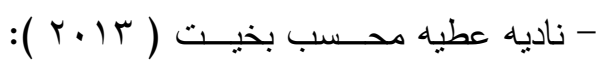
فاعلية استر اتيجية تعليمية مقترحة قائيـــة على المدخل التو اصلي اللغوي في تتميـــة

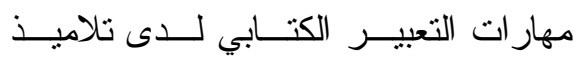
المرحلة الإعدادية، رسالة ماجستير غيــر منشورة، كلية التربية، جامعة المنوفية.

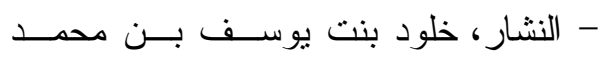
(ץT)

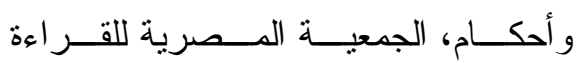
و المعرفة، مجلة القراعة و المعرفة، العـدد פ

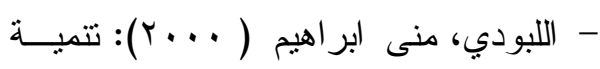

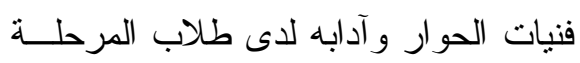

الأمة ( ج ـ 1 ) وز ارة الأوقاف والـشُؤون

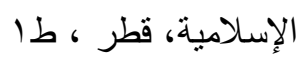

- مجاور، محمد صلاح الـدين ( ب...

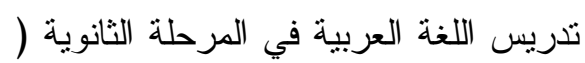

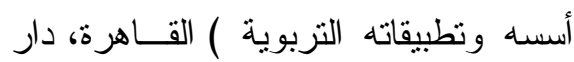
الفكر العربي

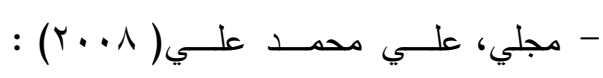
تدريس اللغة الإنجليزية باستخدام الأنشطة

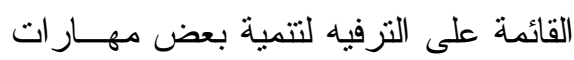

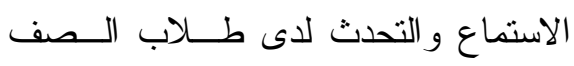
الأول المتوسط، دراسة تجريبيــة رســالة ماجستير غير منشورة، جامعة الملك خالد، كلية التربية

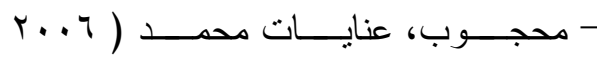

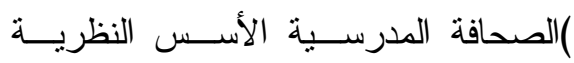
و النطبيقات العملية، القاهرة ، دار الفكـر العربي

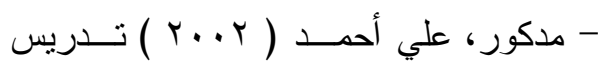

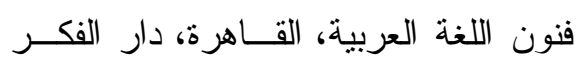

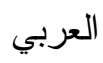

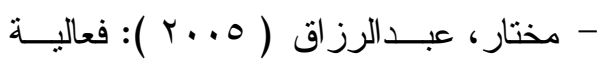
استر اتيجية مقترحة للتغير المفهومي فـي

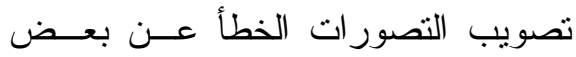
المفاهيم النحوية لدى تلاميذ الصف الثاني الإعدادي، مجلة كلية التربية (، (1)

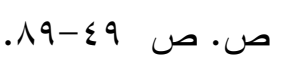


( eric document reproduction service, No ED432005

- Ma , T, ( 2009 ). An Emprical study on teaching listening clt . inter national Education studies , 2 (2) , 126-134

- Shang. H ( 2005 ), listening strategy use and linguistic ratterns in listening comprehension by EFL learners the intel journal of listening, (22) , 4-29.

- Opel, A (2008) the effect of preschool dialogic reading in speaking and vocabulary among rural Bangladesh children, $\mathrm{PH}$. $\mathrm{D}$ thesis mefill university .

- Swan , F (2009) ) Essential principles of the communication Approach journal of teaching , 1 (1) , 2-6.
الثانوية، رسالة دكتور اة غيـر منـشئورة،

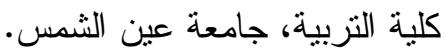

- يونس، فتحسي علـي (1999): اللغــة

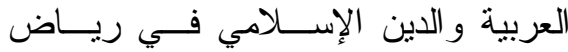

و المدرسة الابتدائية، القاهرة، دار الثقافة .

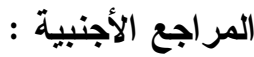

-B rumlit, and . Johnson (b1983) the communicative Approch to language teaching, oxford university . press

- Chung , 1 . ( 2007) . communicative Approach to teaching grammar : theory and practice . the English teacher , 3 : 99-200

- Edigen , M (1999) : listening and reading in the elementary school 